\title{
marife
}

dini araștırmalar dergisi

Turkish Journal of Religious Studies

cilt / volume: 18 • sayı / issue: 2 • kış / winter 2018

\section{Necis Şeylerin Faydalanılabilirlik Bağlamında Flkhî Açıdan Değerlendirilmesi}

\section{Hüseyin Baysa}

Dr. Öğr. Üyesi, Kilis 7 Aralık Üniversitesi İlahiyat Fakültesi

Temel İslam Bilimleri Bölümü İslam Hukuku Ana Bilim Dalı

huseyinbaysa@kilis.edu.tr | http://orcid.org/0000-0003-0406-1102

Geliş Tarihi / Received: 01.06.2018 • Yayına Kabul Tarihi / Accepted: 30.10.2018

$\ddot{O} z$

Necis maddeler geçmişe nispetle daha çok alanda ve daha çok miktarda günlük hayata dâhil edilmiş bulunmaktadır. Bu durum, necis niteliğini taşıyan şeylerden faydalanmanın hükmünü yeniden düşünmeyi zorunlu hale getirmiştir. Nitekim bu saikle son yıllarda helâl gıda, helâl giyim, helâl kozmetik ve istihâle gibi başlıklar altında bireysel ve kolektif çapta bilimsel çalışmalar gerçekleștirilmektedir. Bu tür çalışmalarda isabetli bir sonuç elde edilebilmesi için öncelikle necis şeylerin faydalanılabilirliğinin fikhî açıdan etüt edilmesi önem arz etmektedir. Bu yönde yapılacak araștırmalar neticesinde ulaşllacak veri, necis şeylerden faydalanmaya ilişkin güncel fikhî problemlerin çözümünde kullanılacak temel ilkelerin oluşturulmasına katkı sağlayacaktır. Bu amaçla yapılan bu araștırmada, nasslar ve fukahânın yaklașımları değerlendirilerek necis șeylerden faydalanma imkânı tartışılmaktadır. Makalenin birinci kısmında necis niteliğini taşıyan maddeler, nasslarda bahsinin geçip geçmemesi ve hakkındaki tahrîmin mutlak olup olmaması açısından değerlendirmeye tabi tutulmaktadır. İkinci kısmında ise yapısal değişime uğramış olmanın, necâsetin hükmü üzerindeki etkisi tespit edilmeye çalışlmaktadır. Anahtar Kelimeler: Fıkıh, Necis, İstihâle, Helâl Ürün, Faydalanılabilirlik.

\footnotetext{
The Evaluation of Impure Things in the Context of Possibility of Utilizing from the Fiqh Perspective

Impure materials are encountered more often in the daily life than in the past. This situation has made it necessary to rethink the rules of using things that are impure. As a matter of fact, this motive individual and collective scale scientific studies have been carried out in recent years under the titles of halal food, halal clothing, halal cosmetics and metamorphism. In order to obtain a correct result in such studies, it is important firstly to examine the opportunity to benefit from impure things in a fiqhi way. The data to be provided in the context of the studies that to be carried out in this direction will contribute to the establishment of the basic principles which are used in the solution of contemporary fiqh problems related to benefit from unclean things. In this study which was done for this purpose are discussed the possibility of using impure things by evaluating the texts and scribes (fuqaha) approaches. In the first part of the article, things that have an impure nature of have been assessed in terms of whether or not the has passed and the prohibition about it is absolute. In the second part, we tried to determine the effect of the structural change on the rule of impurity.

Keywords: Fiqh, Impure, Metamorphism, Halal Product, Opportunity to Benefit.
}

\section{Atıf / Cite as}

Baysa, Hüseyin. "Necis Şeylerin Faydalanılabilirlik Bağlamında Fıkhî Açıdan Değerlendirilmesi”. Marife 18/2 (2018): 329-352. https://doi.org/10.33420/marife.429802. 


\section{Giriş}

Sağlıklı bir hayat için yaşam malzemelerinin zararlı mikroorganizmalardan arındırılması oldukça önem arz etmektedir. Günümüzde bu anlamda dezenfeksiyon, sterilizasyon ve hijyen gibi ifadeler sıkça kullanılmakla birlikte necis şeylerin bir kısmı yaşamsal malzeme haline gelmiştir. Necis maddeler, seküler anlayış ve ekonomik kaygının yanı sıra teknolojik gelişimin etkisiyle geçmişe oranla daha çok alanda ve daha çok miktarda günlük hayata dâhil edilmiş durumdadır. Gıda ürünlerinde kullanılmak üzere domuz kemiği ve derisinden jelatinin imal edilmesi, eșek sütünün besin maddesi olarak sunulması, kozmetik ürünlerde domuz yağı, plasenta ve alkolün kullanılması, bu konuda verilebilecek örneklerden sadece birkaç tanesidir. Necis maddelerin hayatın içine bu kadar çok dâhil edilmesi, beraberinde konunun fikhî hükmünü belirleme gereksinimini doğurmuştur.

Kur'ân ve Sünnet metinlerinde necis olarak bilinen bazı şeylerin hükmüne yer verildiği görülmektedir. Bunlar kan, lâşe, şarap, domuz eti (el-Bakara 2/173; el-Mâide 5/3; el-En'âm 6/145; en-Nahl 16/115), lâşe derisi ${ }^{1}$ ve pençeli kuşlar ile yırtıcı hayvanların etleridir. ${ }^{2}$ Nasslar incelendiğinde söz konusu hükümlerin, bu maddelerin vahyin nazil olduğu dönemde toplumda yaygın olarak karşılaşılan faydalanma biçimlerine ilişkin olduğu anlaşılmaktadır. Bu şeylerden nasslarda zikredilen yöntemlerden farklı şekilde yararlanmanın ve bunların dışındaki pis maddelerden faydalanmanın hükmü ise ictihâd mekanizmasının işletilmesi ile tespit edilmeye çalışılmıştır. Geçmişte bu konularla ilgili üretilen ictihâdlar, o dönemlerde ihtiyaca cevap vermişse de necis maddelerin geçmiştekinden farklı yöntemlerle ve alanlarda kullanıldığı günümüzde ihtiyacı birebir karşılayacak durumda görünmemektedir. Bu sebeple fikıh müdevvenatındaki bilgi ve yorumlarla birlikte konunun yeniden düşünülmesi gerekmektedir. Nitekim son yıllarda necis maddeleri yaşam malzemesine dönüştürmenin hükmü; helâl gıda, helâl ilaç, helâl giyim, helâl kozmetik, istihâle ve istihlâk gibi başlıklar altında bireysel ve kolektif çapta araştırmalara konu edilmektedir. ${ }^{3}$ Göründüğü kadarıyla bu çalışmalar, konu hakkında hem üretici hem de tüketici nezdinde bir duyarlılığın oluşumunda önemli bir etki göstermiş bulunmaktadır. Yapılan çalışmalar bu açıdan takdire şayan olmakla birlikte, çeşitli ürünler ve hizmetlerin helâlliği konusunda farklı görüşlerle sonuçlandığı için pratik değeri açısından beklenen asıl faydayı sağlayabilmiş değildir.

Görünen o ki günümüzde yaşanan helâllik sorununun merkezinde necis şeylerden faydalanmanın hükmüne ilişkin yaklaşım farklılı̆̆ı ile bu tür şeylerin tabi tutulduğu işlemlerin, maddenin yapısal özellikleri üzerindeki etkisine dair görüş ayrılığı yer almaktadır. Helâl konusu ile ilgili fıkhî problemlerin sağlıklı bir şekilde

1 Ebü'l-Huseyn Müslim b. el-Haccâc b. Müslim el-Kușeyrî, el-Câmi'u's-sahîh (Beyrut: Dâru ihyâi'ttürâsi'l-Arabî, ty.), "Hayz", 103; Ebû Îsâ Muhammed b. Îsâ b. Sevre et-Tirmizî, el-Câmi'u'l-kebîr (Beyrut: Dâru'l-garbi'l-Arabî, 1998), "Libâs”, 7.

2 Buhârî, "Zebâih ve's-Sayd”, 29; Müslim, "Sayd ve'z-Zebâih”, 12.

3 İslâm Flkhı Açısından Helâl Gıda (Bursa, 2009) adlı sempozyum ile 1. Ulusal Helâl ve Sağlıklı Gıda Kongresi (Ankara, 2011) bu konuda yapılan önemli çalışmalar arasında zikredilebilir. 
çözümlenebilmesi için mevzubahis hususlarda yeterli ölçüde tetkikatın yapılması ve bunun sonucunda temel ilkelerin belirlenmesi önemli bir ihtiyaç olarak ortada durmaktadır. Bu ihtiyacın karşılanmasına yönelik gerçekleştirilecek araştırmalara katkı sağlamak amacıyla yapılan bu çalışmada necis maddelerden yararlanmanın hükmüne ilişkin nasslar ile fukahânın değerlendirmeleri yorumlanmaya çalışılacaktır. Ayrıca istihâlenin mahiyeti ve fonksiyonu ile ilgili güncel yaklaşımlar tetkik edilecektir.

\section{Necis Kavramı}

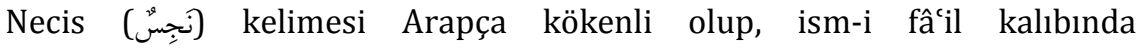
bulunmaktadır. ${ }^{4}$ Türkçede de kullanılan ${ }^{5}$ necis sözcügü lügatte, insan pisliği, ${ }^{6}$ selim tabiat sahiplerinin çirkin gördüğü/tiksindiği ${ }^{7}$ ve temiz olmayan şey gibi anlamlara gelmektedir. ${ }^{8}$ Klasik fıkıh kitaplarında çok yaygın olmamakla birlikte, bu manalar için "neces" (نَجَسُ) kelimesinin de kullanıldığg görülmektedir. ${ }^{9}$

Necis sözcüğü Kur'ân-ı Kerîm'de "pis" anlamında sadece bir yerde ve "neces" şeklinde geçmektedir (et-Tevbe 9/28). Hadislerde bu kökten türeyen çok sayıda kelime bulunmakta ve bunlarla genel olarak kirlilik hali ile dinen pis kabul edilen maddeler ifade edilmektedir.10 Necis kelimesi fıkıh kitaplarında, yenmesi/içilmesi haram olan şey, ${ }^{11}$ şer $^{c} a n$ pis kabul edilen şey ${ }^{12}$ ve namazın

4 Muhammed Ravvâs Kal'acî - Hâmid Sâdık Kanîbî, "Necâset”, Mu'cemü luğğati'l-fukahâ (Beyrut: Dâru'n-nefâis, 1988), 475.

5 Necis kelimesi günlük dilde ve akademik çalışmalarda kullanılmakla birlikte, Türk Dil Kurumu'nun sözlüklerinde yer almamaktadır. Örneğin Diyanet İslam Ansiklopedisi'nde bu sözcük 58 sayfada geçmektedir. Türkiye Diyanet Vakfı İslâm Araştırmaları Merkezi İslam Ansiklopedisi, "Necis”, erişim: 31 Ocak 2018, http://www.islamansiklopedisi.info/.

6 Ebü'l-Fazl b. Manzûr Cemâlüddîn Muhammed b. Mükerrem b. Alî b. Ahmed el-Ensârî, "Ncs", Lisânü’l'Arab (Beyrut: Dâru sâder, 1414h.), 6: 226.

7 Mansûr b. Yûnus b. Salahiddîn el-Buhûtî, Keşşâfü'l-kınâ ' ‘n metni'l-İknấ (b.y.: Dâru'l-kütübi'l-ilmiyye, ty.), 1: 29; Alâüddîn Ebû Bekir b. Mes'ûd el-Kâsânî, Bedâi' 'u's-sanâi' fî tertîbi'ş-şerâi ‘ (Beyrut: Dâru'lkütübi'l-ilmiyye, 1986), 1: 60.

8 Ebü't-Tâhir Mecdüddîn Muhammed b. Ya'kûb b. Muhammed el-Fîrûzâbâdî, "Neces”, el-Kâmûsü'lmuhît (Beyrut: Müessetü'r-risâle, 2005), 576; Muhammed Emin b. Ömer b. Abdilaziz b. Âbidîn, Reddü'l-muhtâr 'ale'd-Dürri'l-Muhtâr (Beyrut: Dâru'l-fikr, 1992), 1: 308; Heyet, "Necâset”, elMevsûatü'l-fikhiyyetü'l-Kuveytiyye (Kuveyt: Vizâratü'l-evkâf ve'ş-şüûni'l-İslâmiyye, 2007), 40: 73.

9 Bk. İbn Âbidîn, Reddü'l-muhtâr, 1: 308. Bu iki sözcüğün farklı anlamlara geldiği de söylenmektedir. Neces kelimesinin sadece aslı itibariyle pis olan şeylerin durumunu ifade etmek üzere kullanıldığı, necis kelimesinin ise hem bu anlamda hem de -çok yaygın olmasa da- sonradan pis hale gelen şeyler için kullanıldığı ifade edilmektedir. Abdurrahmân el-Cezîrî, Kitabü'l-fıkh 'ale'l-mezâhibi'l-erbe'a (Beyrut: Dâru'l-kütübi'l-ilmiyye, 2010), 11.

10 Bk. Arent Jan Wensinck v.dğr., “Ncs”, el-Mu'cemü'l-müfehres li-elfâzi'l-hadîsi'n-nebevî (Leiden: Mektebetü Brill, 1936-1969), 6: 361; Salim Öğüt, "Tahâret”, Türkiye Diyanet Vakfı İslâm Ansiklopedisi (Ankara: TDV Yayınları, 2010), 39: 382.

11 Ebü'l-Abbâs Şihâbüddîn Ahmed b. Ahmed b. Hamza er-Remlî, Nihâyetü'l-muhtâc ilâ şehi'l-Minhâc (Beyrut: Dâru'l-fikr, 1984), 1: 232; Ebü'n-Necâ Şerefüddîn Mûsâ b. Ahmed b. Mûsâ el-Haccâvî el-

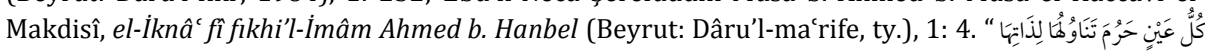

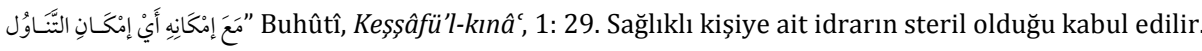
hayatisaglik.com, “Normal idrarın özellikleri nelerdir?”, erişim: 23 Ağustos 2017, http://www.hayatisaglik.com/laboratuvar/normal-idrarin-ozellikleri-nelerdir.html. Buna göre, her 
sıhhatine engel olan pislik ${ }^{13}$ olarak tanımlanmıştır. Necis şeyler yenmesi/içilmesi haram olan, şer'an pis kabul edilen ve namazın sıhhatine engel olan şeylerdir. Bu açıdan tarifler arasında herhangi bir tenakuz görünmemektedir. Ancak tanımlama tekniği açısından bakınca birinci tarifin "ağyârını mâni”" olmaması itibariyle sorunlu olduğu anlaşılmaktadır. Çünkü necis olan şeylerin yenmesi haram olduğu halde yenmesi haram olan her şey necis değildir. Örneğin esrar, eroin vb. uyuşturucu maddelerin insan tarafından tüketilmesi haram olmakla birlikte necis olmadığı bilinmektedir. Necâsetin farklı yönlerini vurgulayan son iki tarifte ise böyle bir sorun görünmemektedir.

Necis kelimesi daha çok nitelik bildirmek üzere kullanılmaktadır. Necis niteliğini taşıyan maddelere "necâset" (نجَاسَةُ denir. "Pislik" anlamına gelen necâsetin hakikî ve hükmî olmak üzere iki çeşidi bulunmaktadır. Hakikî necâset, yukarıda tarifini verdiğimiz necâsettir. Hükmî necâset ise Hanefîler'e göre hades (abdestsizlik) halidir. ${ }^{14}$ Ancak Hanbelîler ile Şâfiîler bu kavrama daha farklı anlamlar yüklemişlerdir. Hanbelîler "hükmî necâset" ibaresi ile temizlenmesi mümkün olan pis şeyleri kastederken, ${ }^{15}$ Şâfiîler bu kavramı kurumuş idrar gibi pisliği duyu organları ile anlaşılamayan şeyler için kullanmışlardır. ${ }^{16}$ Çalışmamızda hakikî necâsetin faydalanılabilirliği ele alınacaktır. Bu çeşit necâset, namazın sıhhatine engel olup olmaması açısından ğalîze (ağır) ve hafîfe (hafif) olmak üzere iki kısma ayırılmıștır. Necâset-i ğalîze, necis olduğu hususunda ihtilafa mahal bırakmayacak şekilde hakkında açık nass bulunan, kan ve dışkı gibi şeylerdir. Necâset-i hafîfe ise hakkında farklı yorumlanmaya müsait nass bulunan ve dolayısıyla necis olduğu hususunda âlimlerin ihtilaf ettikleri, eti yenen hayvanların idrarı gibi şeylerdir. Hanefîler ${ }^{17}$ ile Mâlikîler'de ${ }^{18}$ necâset çeşitlerine dair taksim ve tanımlama genel olarak bu şekildedir. Şâfiîler bu sınıflandırmaya üçüncü bir çeşit olarak "mütevessıta" (orta dereceli) necâseti eklemişlerdir. Onlar, sadece domuz ve köpek ile bunların bulaştığı şeyleri necâset-i ğalîze, erkek süt çocuğunun idrarını necâset-i hafîfe, bunların dışındaki necis maddeleri ise orta dereceli necâset olarak kabul etmişlerdir. ${ }^{19}$ Necâsetin mahiyeti ve çeşitleri konusu,

necis olan șeyin aynı zamanda mikroplu olduğunu veya hijyenik olan her şeyin șer`an temiz olduğunu söylemek doğru olmaz.

12 Zeynüddîn b. İbrâhîm b. Nüceym, el-Bahru'r-râik şerhu Kenzi'd-dekâik (b.y.: Dâru'l-kütübi'l-İslâmî, ty.), 1: 232.

13 Şemsüddîn Muhammed b. Ahmed el-Hatîb eş-Şirbînî, Mugni'l-muhtâc ilâ ma'rifeti me ânî elfâzi'lMinhâc (b.y.: Dâru'l-kütübi'l-ilmiyye, 1994), 1: 116; Ebû Abdillâh Şemsüddîn Muhammed b. Muhammed b. Abdirrahmân el-Ma'rûf bi'l-Hattâb er-Ruaynî, Mevâhibü'l-celîl fî şerhi Muhtasârı Halîl (b.y.: Dâru'l-fikr, 1992), 1: 43.

14 Hanefîler buna "takdirî necâset" de demişlerdir. Bk. Kâsânî, Bedâi'u's-sanâic, 1: 68; İbn Âbidîn, Reddü'l-muhtâr, 1: 308; Vizâratü'l-evkâf ve'ş-şüûni'l-İslâmiyye, "Necâset”, 40: 75.

15 Buhûtî, Keşşâfüll-kınâc', 1: 29.

16 Remlî, Nihâyetü'l-muhtâc, 1: 257.

17 Ebû Hanife, bu necâset çeşitlerini belirlerken nassların kat îliğini ve zannîliğini, İmâmeyn ise âlimlerin hüküm hakkındaki ittifak derecesini esas almıştır. Abdullah b. Mahmûd b. Mevdûd Mecdüddîn Ebü'l-Fadl el-Mevsılî, el-İhtiyâr li ta lîli'l-Muhtâr (Kahire: Matba'atü'l-Halebî, 1937), 1: 31; Kal'acî - Kanîbî, "Necâset”, 475; Öğüt, "Tahâret”, 39: 382.

18 Hattâb er-Ruaynî, Mevâhibü'l-celîl, 1: 109.

19 Şirbînî, Mugni'l-muhtâc, 1: 239-241; Remlî, Nihâyetü'l-muhtâc, 1: 253-7. 
araştırmamızın muhtevası dâhilinde olmadığından burada necâset çeşitlerine ilişkin görüşlere bu kadar değinmekle iktifa edeceğiz.

Necis şeylerin bir kısmı kimyevi özelliklerini muhafaza ederken, bir kısmı ise zamanla veya müdahaleler neticesinde bu özelliklerini kaybedip başka maddelere dönüşebilmektedir. Hayvan tersinin yanıp kül haline gelmesi, zeytinyağının sabuna dönüştürülmesi ve şarabın sirkeleșmesi, fıkıh kitaplarında, kendisinde başkalaşım gerçekleșen necis maddelere verilen örneklerdendir. Necis șeylerin faydalanılabilirliği irdelenirken, necâsetin bu durumunun da göz önünde bulundurulması gerekmektedir. Bu sebeple, konuyu necis maddelerin değişime uğramış olup olmaması açısından başlıklandırarak işlemeye çalışacağız.

\section{Değișime Uğramamış Necis Şeylerden Faydalanma İmkânı}

Fukahâ, kimyevi özellikleri değişmemiş necis şeylerden faydalanma imkânını ele alırken naslarda bahsinin geçip geçmediğine ve geçmişse mutlak olarak haram kılınıp kılınmamış olmasına göre bunları ayrı ayrı değerlendirmelere tabi tutmuştur. Konuyla ilgili sağlıklı değerlendirmelerde bulunabilmek için araştırma bu kategorizasyon doğrultusunda sürdürülecektir.

\subsection{Nasslarla Haram Kılınmıș Necis Șeylerden Faydalanmak}

Nasslarla haram kılınmış şeylerin bir kısmının necisliği hakkında icmâ meydana gelmişken bir kısmının necisliği ise ihtilaflıdır. Necis olduğu hususunda fukahânın görüş birliği ettiği veya buna yakın bir konsensüsün meydana geldiği şeyler şarap, ${ }^{20}$ hayvanın bedeninden ayrılıp akan kan, domuz eti ve kendiliğinden yahut usulüne uygun kesilmeden ölmüş hayvanın etidir. ${ }^{21} \mathrm{Bu}$ maddelerin insan gıdası olarak tüketilmesi ayetlerle haram kılınmıștır (el-Bakara 2/173; el-Mâide 5/3; el-En'âm 6/145; en-Nahl 16/115). Hz. Peygamber ayrıca bu maddelerin insan gıdası haricindeki alanlarda kullanılmasını ve ticari akde konu edilmesini de menetmiştir. 0, Mekke'nin fethedildiği yıl şarap, meyte ve domuz satışının haram olduğunu bildirmiştir. Bunu duyan sahabîler, kendisine lâşe yağının, gemi ve deri

${ }^{20}$ Kâsânî, Bedâicu's-sanâic, 5: 113. Kur'ân'da şarap, pislik anlamına gelen "rics" kelimesi ile nitelendirildiği (el-Mâide 5/90) için fakihlerin kahir ekseriyeti şarabın necis olduğunu söylemişlerdir; ancak bazı âlimler, Kur'ân'da cennetliklere lezzetli şarap nehirlerinin müjdelendiğini, cennet ehline yapılacak ikramın ise necis olamayacağını belirterek (Muhammed 47/15) şarabın necis olmadığını iddia etmişlerdir (Bk. Ebü'l-Hasen Alî b. Muhammed b. Habîb el-Basrî el-Mâverdî, elHâvi'l-kebîr (Beyrut: Dâru'l-kütübi'l-ilmiyye, 1999), 2: 259-260). Ayrıca bazı bitkiler zehirleyici veya uyuşturucu olduğu için zorunlu olmadıkça kullanmak haram olduğu halde bunların necis olmadığını söyleyerek şarabın da uyușturucu özelliği bulunmakla birlikte necis olmadığını ileri sürmüşlerdir (Bk. Ebû Zekeriya Muhyiddîn b. Yahya b. Şeref en-Nevevî, el-Mecmûc șerhu'l-Mühezzeb (b.y.: Dâru'lfikr, ty.), 2: 563). Ancak bu iddia, sözü edilen cennetteki șarabın bașka bir ayette "tertemiz" vasfıyla nitelendiği (el-İnsân 76/21) ve dolayısıyla onun dünyadaki şaraptan farklı olduğu söylenerek cevaplanmiștır. Şirbînî, Mugni'l-muhtâc, 1: 225.

${ }^{21}$ Ebü'l-Velîd Muhammed b. Ahmed b. Rüșd el-Kurtubî, Bidâyetü'l-müctehid ve nihâyetü'l-muktesid (Beyrut: Dâru'l-kütübi'l-ilmiyye, 2010), 537; Ebü'l-Fazl Şihâbüddîn Ahmed b. Alî b. Muhammed b. Hacer el-Askalânî, Fethu'l-bârî bi-șerhi Sahîhi'l-Buhârî (Beyrut: Dâru'l-ma'rife, 1379h.), 4: 425; Ahmed b. Muhammed b. Ebî Bekr el-Kastalânî, İrşâdü's-sârî li şerhi Sahîhi'l-Buhârî (Mısır: el-Matbaa'tü'lkübrâ el-emîriyye, 1323h.), 4: 114; Ebû Zekeriya Muhyiddîn b. Yahya b. Şeref en-Nevevî, el-Minhâc şerhu Sahîhi Müslim (Beyrut: Dâru ihyâi't-türâsi'l-Arabî, 1392h.), 11: 7. 
yağlama ile aydınlatmada kullanıldığını hatırlatarak hükmünü tekrar sormuşlar. Bunun üzerine Hz. Peygamber, "Hayır, o haramdır." (لا، هو حرام) demiş ve peşinden yahudilere hayvan yağının yasaklandığını, onların ise yağı eritip sattıklarını anlatıp, bu yaptıklarını kınamıștır. ${ }^{22} \mathrm{~Hz}$. Peygamber'in lâșe yağına ilişkin soruya verdiği "Hayır, o haramdır." şeklindeki cevap, fukahâ tarafından iki şekilde yorumlanmıştır. Hanbelîler bu yanıtla lâşe yağını rivayette bahsi geçen alanlarda kullanmanın haramlığının kastedildiğini düşünürken, ${ }^{23}$ başta Şâfiîler ve Hanefîler olmak üzere fukahânın çoğunluğu ise Hz. Peygamber'in bu sözünden lâşe yağının satışına ilişkin yasaklayıcı hükmün teyit edildiğini anlamışlardır. ${ }^{24}$ İkinci görüşü savunanlardan Şâfiîler, bu düşünceleri doğrultusunda lâşe yağını, deri ve gemi yağlama ile aydınlatmada kullanmanın caiz olduğunu söylemiş̧lerdir. ${ }^{25}$ Hanefîler ise konuyla ilgili başka nasslara dayanarak bu yağdan hiçbir şekilde faydalanmanın caiz olmadığı sonucuna varmışlardır. ${ }^{26}$ Onların istinbatta bulundukları rivayetlerden birine göre, bir grup insan deve lâşesinin yağıyla gemilerini yağlamak için Hz. Peygamber'den izin istemiştir. 0 da "Lâşenin hiçbir şeyinden/lâşeden hiçbir şekilde faydalanmayın." diyerek onları bundan menetmiştir. ${ }^{27} \mathrm{Bu}$ hadisi esas alan Hanefîler ${ }^{28}$ ile bir nakle göre İmam Mâlik ${ }^{29}$ lâşenin eti ve yağından hiçbir şekilde faydalanmayı tecviz etmemişlerdir. Bu görüşlerini ayrıca ilgili ayetlerde lâşenin mutlak olarak haram kılınmış olması ve önemle ondan sakındırılmış olmasıyla temellendirmişlerdir. ${ }^{30}$

22 "أرأيت شحوم الميتة فإنها يطلى بها السفن، ويدهن بها الجلود، ويستصبح بها الناس؟ قـال: لا، هـو حـرام" Buhârî, "Büyû'”, 111; Müslim, "Müsâkât", 71.

${ }^{23}$ Ebû Muhammed Abdullah b. Ahmed b. Kudâme el-Makdisî, el-Muğnî (b.y.: Mektebetü'l-Kahire, 1968), 9: 428; Buhûtî, Keşşâfü'l-kınấ, 3: 156.

${ }^{24}$ Ebü'l-Hasen Alî b. Halef b. Abdilmelik b. Battâl el-Bekrî el-Kurtubî, Şerhu Sahîhi'l-Buhârî (Riyad: Mektebetü'r-rüșd, 2003), 6: 361; İbn Hacer, Fethu'l-bârî, 4: 425; Kastalânî, İrşâdü's-sârî, 4: 114; Muhammed b. Ali b. Muhammed eş-Şevkânî, Neylü'l-evtâr şerhu Münteka'l-ahbâr (Lübnan: Beytü'lefkâri'd-düveliyye, 2004), 974; Bk. Hüseyin Baysa, "Hayvansal Yan Ürünlerin Ticaretinde Helâllik Sorunu”, Íslam Hukuku Araştırmaları Dergisi 30 (Ekim 2017): 435.

25 Mâverdî, el-Hâvi'l-kebîr, 15: 159; Nevevî, el-Minhâc, 11: 6.

${ }^{26}$ Hanefîler'den meyte yağını mescid dışındaki yerlerde aydınlatmaya cevaz verenler olmuştur. Ancak bu cevazın, lâşe yağını mütekavvim olarak değerlendirdikleri anlamına gelmediğini de özellikle belirtmișlerdir. İbn Âbidîn, Reddü'l-muhtâr, 6: 183.

27 Delil olarak kullanılan rivayette Hz. Peygamber'e nispet edilen "Lâşeden hiçbir şekilde yararlanmayın." (لاتتفعـوا مـن الميتـة بشي-) ifadesini meşhur sahih hadis kaynaklarında göremedik. Ancak anlam itibariyle bu rivayeti destekleyen şöyle bir hadis bulunmaktadır: "Lâşenin ne derisinden ne de sinirinden faydalanın.” (لا تتنفعوا من الميتة بإهاب ولا عصب). Tirmizî “Libâs”, 7; Nesâî, "Fer' ve'l-'Atîra”, 5.

28 Muhammed b. Ahmed Şemsü'l-Eimme es-Serahsî, el-Mebsût (Beyrut: Dâru'l-ma'rife, 1993), 10: 197-8; Ebû Ca'fer Ahmed b. Muhammed b. Selâme el-Ezdî el-Hacrî el-Misrî et-Tahâvî, Şerhu me'âni'l-âsâr (Beyrut: Dâru'l-kütübi'l-ilmiyye, 1399h.), 1: 468-9.

29 İmam Mâlik, köpek ve diğer yırtıcı hayvanların lâşeyi kendi kendilerine yemeleri durumunda onlara karıșılmayacağını da söylemiștir. Ebû Abdillâh Muhammed b. Ahmed el-Kurtubî, el-Câmiu' liahkâmi'l-Kur'ân (Kahire: Dâru'l-kütübi'l-Misriyye, 1964), 2: 218.

30 Ebû Bekr Ahmed b. Ali er-Râzî el-Cessâs, Ahkâmü'l-Kur'ân (Beyrut: Dâru'l-kütübi'l-ilmiyye, 1994), 1: 130; İbn Âbidîn, Reddü'l-muhtâr, 6: 183; Ebû Abdillâh Muhammed et-Tâhir b. Muhammed b. Muhammed eș-Şâzelî b. Âşûr, et-Tahrîr ve't-tenvîr (Tunus: ed-Dâru't-Tûnusiyye, 1984), 2: 116; Bk. Baysa, "Hayvansal Yan Ürünlerin Ticaretinde Helâllik Sorunu”, 430-431. 
Aktardığımız bu bilgilerden anlaşıldığı üzere, nasslarda bahsi geçen ve necisliği hakkında icmâ veya icmâya yakın bir uzlaşının bulunduğu şeylerin faydalanılabilirliği konusunda fakihler ihtilaf etmişlerdir. Bu durum, ilgili nassların teâruzune bağlanmıştır. ${ }^{31}$ Ancak konuyla ilgili rivayetlerin, fikhın temel kurallarına aykırı bulunmasının ve delâleti zannî nassların varlığı da diğer meselelerde olduğu gibi burada da ihtilafın oluşmasına zemin hazırlamıştır. Nasslarda farklı anlaşılmaya imkân vermeyecek şekilde haram kılındığı bildirilen necis şeylerden yararlanmanın caiz olmadı̆̆ı konusunda aykırı herhangi bir görüş ortaya çlkmamıştır. Örneğin zarurî durumlar dışında lâşeden yemenin haram olduğu hususunda icmâ oluşmuştur. Nassî dayanağı farklı yorumlanmaya müsait olan necis maddelerden faydalanmanın hükmü konusunda ise farklı görüşler sadır olmuştur. Biraz önce değindiğimiz lâşe yağını aydınlatmada kullanmanın hükmü ile ilgili tartışmalar, bunun tipik örneklerindendir.

Şunun da belirtilmesi gerekiyor ki, söz konusu necis şeylerden faydalanmanın hükmü hakkında her ne kadar görüş ayrılığı meydana gelmişse de bu tür şeyleri ticari sözleşmeye konu etmenin caiz olmadı̆̆ gerçekleşmiştir. Burada icmâı sağlayan temel faktör, sözü edilen şeylerin satışının haram kılındığını bildiren hadisteki açık ifadelerdir. ${ }^{32}$ Fukahâ yukarıda verdiğimiz bu hadisteki haram hükmünün mutlaklığına dayanarak, bu maddeleri insan veya hayvan tüketimi için yahut başka bir işte kullanmak amacıyla satın almanın hükmü arasında herhangi bir ayırım yapmamıştır. ${ }^{33}$

Nasslarda bahsi geçip de necis olup olmadığı hususunda fukahânın ihtilaf ettiği maddelerden faydalanmanın hükmü hakkında da farklı görüşler ortaya konulmuştur. Örneğin köpeğin necisliği, köpek edinmenin ve alım satımını yapmanın hükmü hakkında farklı yaklaşımlar bulunmaktadır. Köpeğin salyasının bulaştığı kabı döküp yıkamayı emreden ${ }^{34}$ ve köpeğin satışını meneden ${ }^{35}$ rivayetlerden yola çıkan Şâfiîler ile Hanbelîler köpeğin necis olduğunu söylemişlerdir. ${ }^{36}$ Ancak köpeğin sadece avcılık, çobanlık ve bekçilikte kullanılmak üzere beslenebileceğini bildiren rivayetlere ${ }^{37}$ dayanarak bu amaçlarla köpek edinmeyi mubah görmüşlerdir. ${ }^{38}$ Bununla birlikte necisliğini ve satışını meneden

31 İbn Rüșd, Bidâyetü'l-müctehid, 538.

32 İbn Hacer, Fethu'l-bârî, 4: 425-6.

33 Mâverdî, el-Hâvi'l-kebîr, 15: 159; Nevevî, el-Minhâc, 11: 8; Serahsî, el-Mebsût, 24: 24; Ebü'l-Me'âlî Burhânüddîn Mahmûd el-Buhârî, el-Muhîtu'l-Burhânî fi'l-fikhi'n-Nu'mânî (Beyrut: Dâru'l-kütübi'lilmiyye, 2004), 5: 496; İbn Kudâme, el-Muğnî, 4: 192; İbn Rüşd, Bidâyetü'l-müctehid, 537; İbn Âbidîn, Reddü'l-muhtâr, 6: 183. Lâşenin etçil hayvana yedirilmek üzere ticari akde konu edilmesinin hükmü için bk. Baysa, "Hayvansal Yan Ürünlerin Ticaretinde Helâllik Sorunu”, 435.

34 Müslim, "Tahâret", 89.

35 Buhârî, “Büyû'”, 112.

36 Ebû Abdillâh Muhammed b. İdrîs b. Abbâs eş-Şâfiî, el-Ümm (Beyrut: Dâru'l-fikr, 1990), 7: 202; Mâverdî, el-Hâvi'l-kebîr, 1: 304-305; İbn Kudâme, el-Mugnî, 1: 35-36.

37 “Ziraat veya sürü köpeği dışında köpek besleyen kimsenin ecrinden her gün bir kırat eksilir." ( مَنْ أَمْنَكَ

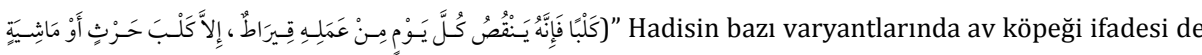
geçmektedir. Buhârî, "Müzâra'a”, 3.

38 Mâverdî, el-Hâvi'l-kebîr, 15: 159; Şirbînî, Mugni'l-muhtâc, 3: 284; İbn Kudâme, el-Muğnî, 4: 192; Buhûtî, Keşşâfül'-kınâ', 4: 368. 
rivayetleri dikkate alarak köpek alım satımına cevaz vermemişlerdir. ${ }^{39}$ Hanefîler ${ }^{40}$ ile bütün canlıların temiz olduğunu iddia eden Mâlikîler ise köpeğin temiz olduğunu kabul etmişlerdir. ${ }^{41} \mathrm{Bu}$ fakihler de sözü edilen rivayetlere dayanarak köpeklerin sadece avcılık, çobanlık ve bekçilikte kullanılmasına cevaz vermişlerdir. Ancak bu işler için eğitilmiş köpekleri alıp satmanın hükmü hakkında Mâlikîler'de mubah, haram ve mekruh şeklinde üç farklı görüş bulunmaktadır. Hadiste faydalanılmasına izin verilenlerin dışındaki köpekler ise ücretinden sakındıran hadisin kapsamı dâhilinde değerlendirilmiş ve bu tür köpeklerin alınıp satılmasının caiz olmadığı yönünde mezhepte ittifak hâsıl olmuştur. ${ }^{42}$ Hanefîler, Mâlikîler'den farklı olarak köpek alım satımını mutlak olarak mubah görmüşlerdir. Eğitimsiz köpeğin sözü edilen alanlarda faydalanılmak üzere yetiştirilebileceğini belirterek köpeği alıp satmanın hükmü konusunda, eğitimli olup olmaması arasında bir ayırım yapmamışlardır. ${ }^{43}$ Köpeğin faydalanılabilir niteliğine ilişkin bu bilgilerden anlaşıldığı üzere fukahâ bekçilik ve avcılık gibi konularda yararlanmak için köpek beslemeye cevaz vermiştir; bu amaçla alıp satmak ise daha çok Hanefilerce mubah görülmüştür. ${ }^{4}$

Nasslarda sadece belli şekilde yararlanılması haram kılınan ve satışı hakkında hüküm bildirilmeyen necis şeyler de vardır. Bu maddeler satışı mutlak olarak haram kılınan necis maddelerden farklı bir kategoriyi oluşturmaktadır. Bunlardan haram kılınmamış yöntemlerle faydalanmanın caizliği hususunda fukahâ arasında neredeyse ittifak meydana gelmiştir; ancak bu maddelerin satışa konu edilmesinin hükmü hakkında iki farklı yaklaşım ortaya çıkmıştır. Örneğin yırtıcı ve saldırgan hayvanların etini, eğitimli etçil hayvanlara yedirmenin hükmü konusunda kayda değer bir ihtilaf bulunmamakla birlikte, eti bu amaçla alıp satmanın hükmü konusunda iki farklı görüş mevcuttur. İlgili nasslar incelendiğinde sözü edilen hayvanların etinin insanlar için haram olduğunu bildiren ifadelerin yer aldığ görülmektedir. ${ }^{45}$ Ancak bu tür hayvanların etlerini eğitimli etçil hayvanlara yedirmenin ve bu amaçla ticari akde konu etmenin hükmüne ilişkin yasaklayıcı

39 Şâfî̂, el-Ümm, 2: 253; Mâverdî, el-Hâvi'l-kebîr, 15: 159; İbn Kudâme, el-Muğnî, 4: 189-190 Buhûtî, Keşşâfül'-kınâ', 4: 78.

${ }^{40}$ Hanefî̀ mezhebine göre köpeğin eti ve salyası necistir. İmâmeyn köpeğin vücudunun dış yüzeyini de necis saymıştır. Ebû Hanife ise temiz kabul etmiş ve mezhepte bu görüş tercih edilmiştir. Hanefi fukahâsı, köpeğin necîsü'l-ayn olmadığı yönündeki görüşlerini temellendirirken, rivayetlerde köpeğin birtakım alanlarda istihdam edilmesine ruhsat verilmiș olmasını gerekçe göstermişlerdir. Serahsî, el-Mebsût, 11: 235; Kâsânî, Bedâi'u's-sanâi' 1: 63-64; 5: 143; İbn Âbidîn, Reddü'l-muhtâr, 1: 208

41 Ebü'l-Abbâs Şihâbüddîn Ahmed b. İdrîs el-Karâfî, ez-Zahîra (Beyrut: Dâru'l-garbi'l-İslâmî, 1994), 1: 166, 179; Hattâb er-Ruaynî, Mevâhibü'l-celîl, 4: 262; Ahmed b. Guneym b. Sâlim Şihâbiddîn en-Nefrâvî el-Ezherî, el-Fevâkihü'd-devânî 'alâ Risâleti İbn Ebî Zeyd el-Kayravânî (b.y.: Dâru'l-fikr, 1995), 1: 388.

42 İbn Rüşd, Bidâyetü'l-müctehid, 538.

43 Serahsî, el-Mebsût, 11: 235; Kâsânî, Bedâiu's-sanâi', 5: 142-143.

44 Günümüzde sivil savunmada ve polisiye ișlerde kullanmak gibi bir ihtiyacı karşılamak üzere köpek beslemek, rivayetlerde müsaade edilen meşru faydalanma kapsamında yer almaktadır. Dolayısıyla bu tür amaçlarla köpek alım satımı da mubahtır. Sadece hobi olarak dairenin içinde köpek beslemek ve bu amaçla satın almak ise köpek edinmekten sakındıran rivayetlerin yanı sıra hayvan hürriyetini kısıtlama, israf ve insan sağlı̆̆ı açısından ayrıca değerlendirmeye tabi tutulmalıdır.

45 Buhârî, "Zebâih ve's-Sayd”, 29; Müslim, "Sayd ve'z-Zebâih”, 12. 
herhangi bir ifade bulunmamaktadır. Hanefîler bu durumu göz önünde bulundurarak eğitimli hayvanları, bu hayvanların etiyle beslemekte bir sakınca görmemişlerdir. Şâfiîler, Hanbelîler ve Mâlikîler'in lâșeyi köpeklere yedirme konusunda verdikleri cevaz ${ }^{46}$ dikkate alınırsa, onların da bu konuda Hanefîler gibi düşündüklerini söylemek mümkündür. Ancak yırtıcı hayvanların etini ve kemiğini, etçil hayvanlara yedirmek üzere satın alma konusunda Hanefîler; Şâfiîler ile Hanbelîler'den ${ }^{47}$ farklı olarak buna cevaz vermişlerdir. ${ }^{48}$

Hakkında yasaklayıcı nass bulunmayan necis şeylerin satışını caiz görmeyen cumhurun dayanağı, yukarda değindiğimiz şarap, meyte ve domuz satışının haram kılındığını bildiren rivayetlerdir. Cumhur, söz konusu hadiste anılan necis maddelerin satışına müsaade edilmemiş olmasından ve bu hadisin bazı varyantlarında geçen "Allah bir şeyin yenilmesini haram kılmışsa ücretini de haram kılmıştır"49 şeklindeki ifadeden, nasslarda satışı hakkında herhangi bir hüküm bulunmayan necis şeylerin ticaretinin de haram olduğu sonucunu çıkarmışlardır.50 Ayrıca onlar, necis şeylerde müslümanlar için bir faydanın bulunmadığını, dolayısıyla böyle bir şeyin satışa konu edilmesi durumunda alınan ücretin haksız/batıl kazanç olacağını ve bunun da ayetle (en-Nisâ 4/29) haram kılındığını söyleyerek görüşlerini temellendirmeye çalışmışlardır. ${ }^{51}$ Hanefîler ise satışı mutlak olarak haram kılınmamış ve insan tüketimi dışında herhangi bir şekilde kendisinden faydalanılabilen necis maddelerin, haram kılınmamış yöntemlerle kendisinden yararlanmak amacıyla satış akdine konu edilebileceğini düşünmüşlerdir. Hanefîler bu kanaatlerini dile getirirken bir şeyin birden fazla faydasının olabileceği ve bunlardan birisinin haram kılınmış olmasının diğerlerini etkilemeyeceği şeklindeki ön kabulden hareket etmişlerdir. ${ }^{22}$ Ayrıca onlar, bu

46 İbn Kudâme, el-Muğnî, 9: 429; Heyet, "Meyte”, el-Mevsûatü'l-fikhiyyetü'l-Kuveytiyye (Kuveyt: Vizâratü'l-evkâf ve'ş-şüûni'l-İslâmiyye, 2007), 39: 393. Mâlikî mezhebinde râcih olan görüş bu yöndedir (Hattâb er-Ruaynî, Mevâhibü'l-celîl, 1: 120. Mâlikîler'e göre yırtıcı kuşların eti helâldir. Dört ayaklı saldırgan hayvanların eti hakkında ise mezhepte haram ve mekruh şeklinde iki görüş bulunmaktadır (İbn Rüșd, Bidâyetü'l-müctehid, 426). Klasik eserlerde yırtıcı hayvanların etini kedi, köpek gibi etçil hayvanlara vermekle ilgili Mâlikîler'e ait herhangi bir görüșle karșllaşmadık. Ancak onların insan tüketimi için caiz gördükleri yırtıcı hayvanların etini, etçil hayvanlara verilmesine de cevaz verdiklerini söylemek mümkündür.

47 Fıkıh kaynaklarında yırtıcı hayvanları, etçil hayvanlara yedirmek üzere satın almanın hükmü hakkında Mâlikî, Şâfiî ve Hanbelî mezheplerinin görüşlerine dair herhangi bir kayda rastlamadık. Bunu o dönemlerde bu türden bir uygulamanın, hakkında fetva verecek derecede yaygın olmadığ ihtimali izah etmek mümkündür. Ancak Mâlikîler'in yırtıcı hayvanların hükmüne ilişkin yaklaşımlarına (Bk. 46. Dipnot) dayanarak etini helal gördükleri yırtıcı hayvanları, etçil hayvanlara yedirmek üzere satışını caiz gördüklerini düşünebiliriz. Şâfiî ile Hanbelî mezheplerinin ise necis şeylerin satışına ilişkin yaklaşımlarını esas alarak onların buna cevaz vermediklerini söyleyebiliriz.

48 Hanefiler bu cevazı verirken yırtıcı hayvanların lâşe niteliğini almamasını șart koşmuşlardır. Bunun için tezkiyeyi (hayvanın usulüne uygun bir şekilde boğazlanmasını) gerekli görmüşlerdir. Serahsî, elMebsût, 12: 20; Kâsânî, Bedâi'u's-sanâi', 5: 142; Burhânüddîn, el-Muhît, 6: 349; İbn Âbidîn, Reddü'lmuhtâr, 5: 226. Bk. Baysa, "Hayvansal Yan Ürünlerin Ticaretinde Helâllik Sorunu", 431.

49 " Ebû Dâvûd, “Büyûc”, 66.

50 Mâverdî, el-Hâvi'l-kebîr, 5: 383; Nevevî, el-Mecmûc, 9: 225; Hattâb er-Ruaynî, Mevâhibü'l-celîl, 4: 259; Nefrâvî, el-Fevâkihü'd-devânî, 1: 389; İbn Hacer, Fethu'l-bârî, 4: 425.

51 Hattâb er-Ruaynî, Mevâhibü'l-celîl, 4: 258.

52 İbn Rüşd, Bidâyetü'l-müctehid, 538. 
düşüncelerini temellendirmek üzere, faydalanılması caiz olan şeylerin satışının da caiz olması gerektiğini; necis şeylerden yararlanmak helâl ise bunları satarak faydalanmanın da helâl olması gerektiğini ileri sürmüşlerdir. ${ }^{53}$

Nasslarda satışının haram kılındığına dair herhangi bir kayıt bulunmayan necis şeylerin alım satımı konusundaki bu iki yaklaşım gerekçeleri ile birlikte değerlendirildiğinde cumhurun ilgili rivayetlerde necis şeylerin satışının haram kılınmış olmasına kıyasla bu tür şeylerin satışını da haram saymış olmaları ilk etapta makul görünmektedir. Ancak bu kıyas işleminde "asl” olarak kabul ettikleri şeyler, bahsimize konu olan necislerden farklı olarak, aynı zamanda rivayetlerde kendisinden faydalanmanın haram olduğu bildirilen șeylerdir. Dolayısıyla nasslarda bazı necis maddelerden yararlanmanın ve bunları satış akdine konu etmenin haram kılınmış olmasından hareketle, kendisinden faydalanılması nasslarla açıkça yasaklanmamış necis şeylerin satışının da haram olduğunu düşünmek, isabetli bir yaklaşım olarak görünmemektedir. Ayrıca cumhurun bu tür şeylerden nasslarda haram kılınmamış yöntemlerle yararlanmayı mubah saymasına karşın bunların satışına ruhsat vermemiş olması çelişkili bir yaklaşım gibi görünmektedir. Öte yandan hakkında Kur'ân ve Sünnet'te açık yasaklayıcı hüküm bulunmayan şeylerin satışının haram olduğuna hükmetmek, ibahâ-i asliye $^{54}$ ilkesine de aykırıdır. Bütün bu değerlendirmeler neticesinde, hakkında yasaklayıcı hüküm bulunmayan necis şeylerin satışı konusunda Hanefîler'e ait görüşün tercihe şayan olduğunu söylemek mümkündür.

\subsection{Nasslarda Bahsi Geçmeyen Necis Şeylerden Faydalanmak}

Nasslarda necis maddelerin sadece bir kısmı, ismi zikredilerek haram kılınmıştır. Bunlar, vahyin nazil olduğu dönemde insanların günlük hayatta sıkça karşılaştıkları şeylerdir. Nasslarda bahsi geçmeyen necis şeylerin insan gıdası olarak kullanılamayacağı konusunda fukahâ arasında aykırı herhangi bir görüş söz konusu olmamıştır. Fakihler, sadece temiz şeylerin insan gıdası olarak helâl kılındığını bildiren ve pis şeyleri bu alanda kullanmaktan sakındıran ayetlere (el-

53 “Sonuç olarak alışverişin cevazı, fayda(lanma)nın helâlliğine bağlıdır." ( والحاصل: أن جواز البيـع يـدور مـع حـل (الانتفـاع Burhânüddîn, el-Muhît, 6: 347. Bazı Hanbelî bilginler de bu konuda Hanefîler gibi düşünmüşlerdir. Şeriatın yasakladığı hariç, temiz olsun olmasın insanın yararlanabileceği her şeyin satışının caiz olduğunu söylemişlerdir. İbn Kudâme, el-Muğnî, 4: 193.

${ }^{54}$ Cumhur, hakkında haram veya necis olduğuna dair delil bulunmayan maddelerin helâl ve temiz olduğunu bir ilke olarak benimsemiştir. Allah'ın yeryüzündeki her şeyi insanlar için yarattığını (elBakara 2/29), göklerdeki ve yeryüzündeki șeyleri insanların hizmetine verdiğini (el-Câsiye 45/13) ve haram kılınan şeyleri tek tek açıkladığını (el-En`âm 6/119) bildiren ayetler, bu görüşün temellendirilmesinde başvurulan nasslardır. Ayrıca Hz. Peygamber'e yağ, peynir ve yaban eşeği etinin hükmü sorulunca "Helâl Allah'ın kitabında helâl kıldığı, haram da Allah'ın kitabında haram kıldığıdır; hakkında bir şey söylemediği ise sizin için affedip serbest bıraktığıdır." anlamındaki hadis de bu görüşün delilleri arasında zikredilmektedir (Tirmizî, "Libâs", 6; İbn Mâce, "Et'ime”, 60). Ancak asıl olanın haramlık veya tevakkuf (haramlığı veya helâlliği asıl kabul etmeyip, delil buluncaya kadar beklemek) olduğunu savunanlar da olmuştur Zeynüddîn b. İbrâhîm b. Nüceym, el-Eşbâh ve'n-nezâir (Beyrut: el-Mektebetü'l-asriyye, 2011), 87-88; Abdülmecîd Mahmûd Salâheyn, Ahkâmü'n-necâsât fi'lfıkhi'l-İslâmî (Cidde: Dâru'l-muctema', 1991), 27-32; İsmail Yalçın, "Fıkıhta Haram Hayvanları Belirleme Sorunu", İslam Hukuku Araştırmaları Dergisi 24 (Ekim 2014): 335. 
Mâide 4/4-5; el-A'râf 7/157) dayanarak nasslarda bahsi geçsin geçmesin, necis maddeleri insanlar için glda malzemesi olarak değerlendirmenin haram olduğuna hükmetmişlerdir. ${ }^{55}$

Hükmü nasslarda açıkça bildirilmeyen necis şeyleri gıda maddesi haricindeki alanlarda değerlendirme konusunda ise bunların faydalanılabilirlik özelliklerine göre hüküm geliştirilmiştir. Bir şeyin mal ${ }^{56}$ sayılması için şer'an temiz olmasını şart koşan Şâfiîler, Hanbelîler ve Mâlikîler, kendisinden yararlanılması mümkün olan necis şeyleri, böyle olmayan necâsetlerden farklı bir değerlendirmeye tabi tutmuşlardır. Hakkında yasaklayıcı herhangi bir nass bulunmayan ve aynı zamanda kendisinden faydalanılabilinen necis șeyleri "muhterem" kavramı ile niteleyip, bunların yarı ayni hak statüsünde "ihtisas hakkı"na konu olabileceğini söylemişlerdir. ${ }^{57}$ Mal için temizliği şart koşmayan Hanefîler ise kendisinden yararlanılması mümkün olan necis şeyleri, mütekavvim mal olarak kabul etmişlerdir. Fıkıh kitaplarında bu konuda birçok örnekle karşılaşmak mümkündür. Onlardan bir tanesi, "ayn"ı itibariyle necis olan hayvan tersi/gübresinden (السَّرْجَيْن/السِّرِقِين) faydalanma meselesidir. Bu maddenin ekini coşturduğunu ve daha çok ürün almaya yaradığını belirten Hanefîler, ${ }^{58}$ hakkında yasaklayıcı herhangi bir nassın bulunmayışını da dikkate alarak bu şekilde kullanımını caiz görmüşlerdir. ${ }^{59}$ Aynı şekilde Mâlikîler ${ }^{60}$ Şâfiîler ve Hanbelîler de yararını göz önünde bulundurarak, hayvan gübresinden faydalanmanın caiz olduğunu söylemişlerdir. ${ }^{61}$

55 Mâverdî, el-Hâvi'l-kebîr, 15: 158; Nevevî, el-Mecmûc, 9: 36; İbn Kudâme, el-Muğnî, 9: 428; Serahsî, elMebsût, 1: 95; Nefrâvî, el-Fevâkihü'd-devânî, 1: 389; İbn Âbidîn, Reddü'l-muhtâr, 6: 183.

56 Hanefîler kendisinden faydalanılması ve alınıp satılması dinen caiz olan şey için "hukuken değerli mal" anlamına gelen "mal-ı mütekavvim" ifadesini kullanmışlardır (Serahsî, el-Mebsût, 11: 255; 12: 20). Bu özelliğe sahip olmayan mala, "hukukî koruma altında olmayan mal" anlamında "gayri mütekavvim mal" demişlerdir (Mevsılî, el-İhtiyâr, 2: 7; Nihat Dalgın, "İslâm Hukukuna Göre Satım Sözleşmesi Açısından Mal Kavramı", Ondokuz Mayıs Üniversitesi İlahiyat Fakültesi Dergisi 11 (1999): 110). Şâfiîler, Mâlikîler ve Hanbelîler ise Hanefîler'in mütekavvim malda aradıkları şartlara sahip şeyler için sadece "mal" kelimesini kullanmışlardır. Onlar hukuken kıymetli olmayan ve kendisinden faydalanılmasına müsaade edilmeyen șeyleri mal saymamışlardır. Nevevî, el-Mecmû́, 9: 226; Ebü'lHasan Alî b. Ahmed b. Mükrim el-Adevî, Hâşiyetü'l-Adevî 'alâ Kifâyeti't-tâlibi'r-rabbânî (Beyrut: Dâru'l-fikr, 1994), 2: 138. Bazı Hanefîler cumhurun bu terminolojisini tercih etmiștir. Bk. Kâsânî, Bedâi'u's-sanâi', 5: 142 .

57 Nevevî, el-Minhâc, 9: 226; Adevî, Hâşiye, 2: 138; Hattâb er-Ruaynî, Mevâhibü'l-celîl, 4: 258; Şirbînî, Mugni'l-muhtâc, 3: 284. Bu değerlendirmeleri doğrultusunda, muhterem malın gasp edilmesi durumunda iadesinin gerektiğini kabul etmişlerdir. Bu tür șeylere muhterem denmesinin sebebi ise bunların itlafı halinde hukuki tazminat gerekmese de itlafının dinen haram kılınmış olmasıdır (Hasan Hacak, İslam Hukukunun Klasik Kaynaklarında Hak Kavramının Analizi (Doktora Tezi, Marmara Üniversitesi, 2000), 176-9). Onlara göre avcılıkta veya bekçilikte kullanılan köpek, hayvan gübresi ve henüz tabaklanmamıș lâşe derisi gibi necis şeyler, sahibi vefat edince mirasçllarına intikal eder. Nevevî, el-Mecmû', 9: 231.

58 Mevsılî, el-İhtiyâr, 4: 162; İbn Âbidîn, Reddü'l-muhtâr, 6: 60.

59 Serahsî, el-Mebsût, 24: 15; Kâsânî, Bedâi'u's-sanâi', 5: 144; Burhânüddîn, el-Muhît, 6: 350; İbn Âbidîn, Reddü'l-muhtâr, 5: 72 .

${ }^{60}$ Bazı Mâlikîler bu konuda Hanefîler'in görüşünü paylaşmışlardır. İbn Rüşd, Bidâyetü'l-müctehid, 537; Hattâb er-Ruaynî, Mevâhibü'l-celîl, 4: 260.

61 İbn Kudâme, el-Muğnî, 4: 192; Ebü'l-Berekât Mecdüddîn Abdüsselâm b. Abdillâh b. el-Hadır İbn Teymiyye el-Harrânî, el-Muharrâr fi'l-fikh 'alâ mezhebi'l-İmâm Ahmed b. Hanbel (Riyad: Mektebetü'lmeârif, 1984), 1: 284; Adevî, Hâşiye, 2: 138; Mâverdî, el-Hâvi'l-kebîr, 15: 162; Nevevî, el-Minhâc, 11: 3. 
Nasslarda bahsi geçmeyen necis şeyleri, ticari sözleşmeye konu etmenin hükmü konusunda ise iki farklı görüş ortaya çımıştır. Şâfiî, Hanbelî ve Mâlikî fakihlere göre bu tür şeyleri alıp satmak caiz değildir. ${ }^{62} \mathrm{Bu}$ mevzuda cumhurdan daha esnek bir yol izleyen Hanefîler ise kendisinden yararlanılması mümkün olan necis maddelerin satıșına cevaz vermișlerdir. Örneğin Mâlikîler, ${ }^{63}$ Şâfiîler ve Hanbelîler hayvan tersinin gübre olarak kullanılmasını mubah görmekle birlikte necis olduğu gerekçesiyle bunun satışına cevaz vermemişlerdir. ${ }^{64}$ Hanefîler ise tarlayı hayvan tersi ile gübrelemeyi haram kılan herhangi bir nassın bulunmayışını ve faydalı oluşunu gerekçe göstererek bu amaçla hayvan tersi alım satımının caiz olduğunu söylemişlerdir. ${ }^{65}$

Cumhur ile Hanefîler'in nasslarda bahsi geçmeyen necis şeyleri alıp satmanın hükmüne ilişkin görüşleri, nasslarda bahsi geçen ancak alım satımına dair herhangi bir hüküm bildirilmeyen necis maddeler hakkındaki görüşleri ile paralellik arz etmektedir. Görüşlerin temellendirilmesi hususunda da her iki taraf aynı tutumu sergilemiştir. $\mathrm{Bu}$ görüşler delilleri ile birlikte yukarda değerlendirildiği için burada tekrar edilmeyecektir.

\section{3. İstihâleye Uğramış Necis Şeylerden Faydalanma İmkânı}

Fukahâ istihâle ${ }^{66}$ geçirmiş necis maddelerden faydalanmanın hükmü konusunda, istihâlenin temizleme fonksiyonuna ilişkin yaklaşımları doğrultusunda

62 Remlî, Nihâyetü'l-muhtâc, 3: 392; Ruaynî, Mevâhibü'l-celîl, 4: 259.

${ }^{63}$ Bazı Mâlikîler de bu konuda Hanefîler'le aynı görüşte olmuşlardır. İbn Rüşd, Bidâyetü'l-müctehid, 537; Hattâb er-Ruaynî, Mevâhibü'l-celîl, 4: 260.

64 İbn Battâl, Șerhu Sahîhi'l-Buhârî, 6: 346; Mâverdî, el-Hâvi'l-kebîr, 5: 383; 15: 159; Nevevî, el-Minhâc, 9 : 226; 11: 3; Adevî, Hâşiye, 2: 138; Şirbînî, Mugni'l-muhtâc, 3: 284; Buhûtî, Keșşâfü'l-kınâc, 3: 156; İbn Kudâme, el-Muğnî, 4: 192; İbn Teymiyye, el-Muharrâr, 1: 284.

65 Serahsî, el-Mebsût, 24: 15; Mevsılî, el-İhtiyâr, 4: 162; İbn Âbidîn, Reddü'l-muhtâr, 5: 72. Bununla birlikte Hanefîler, dışkının hiçbir şeye yaramadığını gerekçe göstererek müstakil olarak satışına cevaz vermemişlerdir. Kâsânî, Bedấi' 'u's-sanâi', 5: 144; Burhânüddîn, el-Muhît, 6: 347, 350.

66 İstihâle sözcügü, "حَح" (hâle) kelimesinden türemiş olup, sözlükte düz bir şeyin eğrilmeye başlaması, imkânsız hale gelmek, dönüşüm (Ebü'l-Fazl b. Manzûr Cemâlüddîn Muhammed b. Mükerrem b. Alî b. Ahmed el-Ensârî, “Hvl”, Lisânü'l-'Arab (Beyrut: Dâru sâder, 1414h.), 11: 185, 189, 195), bir şeyin aslı ve özellikleri itibariyle değişmesi (Heyet, "Tehavvul”, el-Mevsûatü'l-fikhiyyetü'l-Kuveytiyye (Kuveyt: Vizâratü'l-evkâf ve'ş-şüûni'l-İslâmiyye, 2007), 10: 278; Se`dî Ebû Habîb, "Hâle”, el-Kâmûsü'l-fikhî luğğâten ve ıstılâhen (Dımaşk: Dâru'l-fikr, 1988), 105), sıcak suyun soğumasında olduğu gibi görünüşü aynı olmakla birlikte keyfiyetin değişmesi ve kimyasal değişim (Mehmet Erdoğan, "İstihâle", Flkıh ve Hukuk Terimleri Sözlüğü (İstanbul: Ensar Neşriyat, 2005), 263) gibi manalara gelmektedir. Fıkıh kitaplarında istihâle kelimesi, bir kavram olarak ele alınıp tanımına gidilmemiștir; ancak bu kelime bir maddenin, öncekinden farklı bir ismi gerektirecek şekilde mahiyeti ve fiziki özellikleri bakımından başka bir maddeye dönüşmesi anlamında kullanılmıştır (Bk. Kâsânî, Bedâi 'u'ssanâi', 1: 85; İbn Âbidîn, Reddü'l-muhtâr, 1: 315; Hattâb er-Ruaynî, Mevâhibü'l-celîl, 1: 97; Nefrâvî, elFevâkihü'd-devânî, 2: 288; Remlî, Nihâyetü'l-muhtâc, 1: 247; İbn Kudâme, el-Muğnî, 1: 53; Alî Muhyiddîn el-Karadâĝ̂̀ - Alî Yûsuf el-Muhammedî, Fıkhül-kadâya't-tıbbiyyeti'l-mu'âsıra (Beyrut: Dâru'l-beşâiri'l-İslâmiyye, 2006), 204; Yüksel Çayıroğlu, İslam Hukuku'na Göre Helâl Gıda Sorunu (Doktora Tezi, Marmara Üniversitesi, 2013), 215; Abdurrahman Candan, "Doğrulanabilirlik İlkesi Açısından Fıkıh Literatüründeki İstihâle Örnekleri ve Güncel Bazı Tespitler”, Diyanet İlmî Dergi 53/1

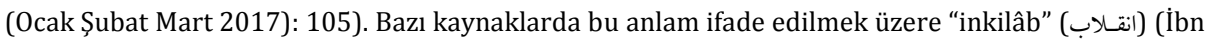


görüş geliştirmiştir. İstihâlenin necis şeyleri temiz hale getirebileceğini düşünenler, bu işlemden geçen necis maddelerin kendisinden faydalanma konusunda temiz şeylerin hükmünü alacağını kabul etmişlerdir. İstihâle neticesinde necisliğin ortadan kalkmayacağını düşünenler ise doğal olarak, istihâleye uğrayan necis şeylerden yararlanılamayacağını söylemişlerdir.

İstihâlenin etkisi konusunda fakihlerin bir kısmı necis eşya arasında herhangi bir ayırım yapmazken, bir kısmı ise aslı temiz olup, kimyasal değişim sonucunda necis hale gelen şeyleri, aslen necis olanlardan farklı değerlendirmiştir. Fukahâ arasındaki bu yaklaşım farkını göz önünde bulundurarak istihâlenin necis maddelerden faydalanmaya etkisini anlatmaya çalışacağız.

\subsection{Sonradan Necis Hale Gelip İstihâleye Uğrayan Şeylerden Faydalanmak}

İstihâle konusunda temel veri olarak kabul edilen nass, şarabın sirkeye dönüşmesiyle helâl olacağını bildiren rivayetlerdir.67 Fukahâ bu rivayetlere dayanarak herhangi bir müdahale olmaksızın şaraptan dönüşen sirkeyi içmenin ve ticari akde konu etmenin helâl olduğu hususunda görüş birliğine varmıștır. ${ }^{68}$ Bunun aklî temellendirilmesi sadedinde ise şarabın necis ve haram olmasına yol açan şeyin, sarhoşluk verici özelliği olduğunu, şarabın sirkeleşmesiyle birlikte bu özelliğin ortadan kalktığını ve necisliğini gerektiren başka bir durum da bulunmadığından artık temiz olduğunu söylemişlerdir. Ayrıca meyve sularının çoğunlukla tahammürden (fermantasyondan) sonra sirkeleştiğini, ${ }^{69}$ şaraptan dönüşen sirkenin temiz olmadığının varsayılması durumunda sirke imalinin mümkün olamayacağını söylemişlerdir. ${ }^{70}$

Başlarda şarap olarak imal edilen içkinin içine tuz ve sirke gibi bir şeyi katarak $^{71}$ veya bulunduğu yeri değiştirerek üretilen sirkenin temizliği konusunda ise âlimler ihtilaf etmişlerdir. Şarabın sirkeleşmekle helâl hale geldiğini mutlak olarak bildiren rivayetleri esas alan Hanefiler'e göre dışardan bir müdahale ile şarabın sirkeye dönüșmesi, kendiliğinden dönüşümü gibidir. Her iki şekilde de

Kudâme, el-Muğnî, 1: 52) ve "teğayyur” (تغيّر) kelimeleri (İbn Âbidîn, Reddü'l-muhtâr, 1: 327, 316) kullanılmıștır.

${ }^{67}$ Ahmed b. el-Huseyn el-Beyhakî, es-Sünenü'l-kübrâ (Beyrut: Dâru'l-kütübi'l-ilmiyye, 2003), "Rehn”, 3.

${ }^{68}$ Hattâb er-Ruaynî, Mevâhibü'l-celîl, 1: 98; Nefrâvî, el-Fevâkihü'd-devânî, 2: 288; Kâsânî, Bedâi'u'ssanâi ' , 1: 113; Nevevî, el-Mecmûc , 2: 578; İbn Kudâme, el-Muğnî, 9: 173; İbn Rüşd, Bidâyetü'l-müctehid, 433.

${ }^{69}$ Sirke, sıvıdaki etil alkolün sirke bakterileri ve havadaki oksijen yardımıyla oksitlenerek asetik aside dönüșmesi sonucunda olușur. Adem Elgün, "Șarabın Sirkeye Dönüșümü", 1. Ulusal Helâl ve Sağlıklı Gıda Kongresi (Ankara, 19-20 Kasım 2011), ed. Fatih Gültekin (b.y.: y.y., 2011), 50.

70 Kâsânî, Bedâi'u's-sanâi', 5: 113; Şirbînî, Mugni'l-muhtâc, 1: 236; Remlî, Nihâyetü'l-muhtâc, 1: 248; Buhûtî, Keşşâfü'l-kınâ', 1: 187.

${ }^{71}$ Günümüzde yapılan deneyler sonucunda içine tuz ve sirke eklenen şarapta herhangi bir değișimin gerçekleşmediği, açık havada bırakılan şarabın ise oksitlenme sonucunda sirkeleştiğinin tespit edildiği ifade edilmektedir (İrfan Yücel, "İstihale-Müzakereler", Güncel Dini Meseleler İstişare Toplantısı IV Günümüzde Helâl Gıda (Afyonkarahisar, 26-28 Kasım 2011), ed. yk. (Ankara: Diyanet İşleri Başkanlığı Yayınları, 2012), 179). Bu bilgi dikkate alınırsa fıkıh kitaplarında şarabın dış müdahale ile sirkeye dönüştürülmesine ilişkin verilen örneklerin o dönemlerdeki mevcut kanaat doğrultusunda oluşturulan varsayımlardan ibaret olduğu söylenebilir. 
şarabın "ayn"ı değișip temiz hale gelmektedir.72 Ayrıca Hanefîler "Sirke, şarabı helâl hale getirdiği gibi tabaklama da derinin mubah olmasını sağlar."73 rivayetini bu konuda temel dayanakları arasında saymışlardır. ${ }^{74}$ Aynı şekilde Hanefîler, bu görüşlerini "Sirke ne güzel katıktır!"75 rivayetindeki sirke kelimesinin mutlak oluşunu gerekçe göstererek ister müdahale neticesinde ister tabii süreci içinde gerçekleşmiş olsun bütün sirke çeşitlerini içerdiğini söylemişlerdir. ${ }^{76}$ Zâhirîler ${ }^{77}$ ile Mâlikîler ${ }^{78}$ de bu görüşü benimsemiştir. Ancak onlar bu şekilde şarabı sirkeye dönüştüren kişinin, onun dökülmesi emrine muhalefet ettiği için günah işlediğini de söylemişlerdir. ${ }^{79}$ Ayrıca Mâlikîler, sirkeleştirmek üzere şarap satın almanın ruhsat verilen bu meseleden farklı olduğunu ve böyle bir sirkeyi içmenin caiz olmadığını söylemişlerdir. ${ }^{80}$

Şaraptan sirke üretmekten meneden rivayetleri esas alan Şafîiler ile Hanbelîler ise şarap olarak imal edilen müskirata bir şey eklemek suretiyle elde edilen sirkenin içilmesini caiz görmemişlerdir. ${ }^{81} \mathrm{Bu}$ rivayetlerden birine göre $\mathrm{Hz}$. Peygamber'e şaraptan sirke yapılıp yapılamayacağı sorulduğunda, o buna olumsuz cevap vermiştir. ${ }^{82}$ Başka bir rivayette ise yetimlere miras kalmış şaraba ne yapılacağının sorulması üzerine Hz. Peygamber'in onun dökülmesini istediği, sirkeleştirilmesi için müsaade istenince buna izin vermediği nakledilmektedir. ${ }^{83}$ Onlara göre sirkeye dönüştürmek şarabı helâl kılacak olsaydı, yetim malının korunmasına düşkün olan Hz. Peygamber onun dökülmesini istemez; sirkeye dönüștürülerek korunmasını emrederdi. ${ }^{84}$ Yine "Sirke ne güzel katıktır."85 hadisindeki sirkenin, şaraptan elde edilen sirke olmadığını, "Sirke şarabı helâl hale getirdiği gibi tabaklama da derinin mubah olmasını sağlar."86 hadisinin ise zayıf olduğunu; sahih olduğu varsayılsa bile burada tabii süreci içinde oluşan sirkenin kastedildiğini ileri sürmüşlerdir.87 Ayrıca sahabe ve tabiînin şaraptan sirke yapmanın caiz olmadığı konusunda icmâ ettiklerini, Hz. Ali'nin şaraptan dönüştürdükleri sirkeyi verebilecekleri endişesiyle şarapçılardan sirke satın almamayı tavsiye ettiğini, Hz. Ömer'in şaraptan faydalanmaktan sakındırdığını

\footnotetext{
72 İbn Âbidîn, Reddü'l-muhtâr, 1: 315.

73 “ Beyhakî bu hadisin zayıf olduğunu söylemiştir. “Rehn”, 3.

${ }^{74}$ Serahsî, el-Mebsût, 24: 23; Kâsânî, Bedâi' 'u's-sanâic, 5: 113.

75 Müslim, "Eşribe”, 164; Ebû Dâvûd, "Et'ime”, 39; Nesâî, "Eymân ve'n-nüzûr", 20.

76 İbn Âbidîn, Reddü'l-muhtâr, 6: 450.

77 Ebû Muhammed Alî b. Ahmed b. Saîd b. Hazm el-Endelüsî el-Kurtubî, el-Muhallâ bi'l-âsâr (Beyrut: Dâru'l-fikr, ty.), 6: 115 .

${ }^{78}$ Mâlikîler'de meşhur olan görüşe göre bu türden sirkeyi içmek mekruhtur. Hattâb er-Ruaynî, Mevâhibü'l-celîl, 1: 98.

79 İbn Hazm, el-Muhallâ, 6: 115.

80 Karâfî, ez-Zahîra, 4: 119.

81 Mâverdî, el-Hâvi'l-kebîr, 6: 112; Nevevî, el-Mecmûc', 2: 574; İbn Kudâme, el-Muğnî, 1: 53; Haccâvî, elİknâ', 1: 60; Buhûtî, Keşşâfü'l-kınâ', 1: 187; İbn Rüşd, Bidâyetül-müctehid, 433.

82 Müslim, "Eșribe", 11; Tirmizî, "Büyû", 59.

83 Ebû Dâvûd, "Eşribe”, 3. Yakın bir rivayet için bk. Tirmizî, "Büyû", 58.

${ }^{84}$ Mâverdî, el-Hâvi'l-kebîr, 6: 113; İbn Kudâme, el-Muğnî, 9: 173.

85 Müslim, "Eşribe", 30; Ebû Dâvûd, "Et'ime”, 39; Nesâî, "Eymân”, 21.

${ }^{86}$ Beyhakî, "Rehn", 3.

87 Mâverdî, el-Hâvi'l-kebîr, 6: 114.
} 
ancak şaraptan kendiliğinden meydana gelen sirkeden yararlanmaya müsaade ettiğini söylemişlerdir. Öte yandan bu görüşlerinin akli temellendirmesini yapmak üzere birtakım çıkarımlarda da bulunmuşlardır. Örneğin akrabalık mirasçılığın sebebi olduğu halde akrabasını öldüren kişinin ona mirasçı olamayışını örnek vererek kendiliğinden sirkeleşen şarabın helâl olduğunu, ancak şarap edinme yasağını çiğneyerek bundan faydalanmanın mubah olamayacağını belirtmişlerdir. ${ }^{88}$ Yine, müdahale neticesinde şaraptan sarhoşluk verme özelliği ortadan kalksa bile sirkeye dönüştürmek için şaraba katılan şeylerin şaraba bulaşmak suretiyle necisleștiğini ve bunun şaraptan elde edilen sirkeye sirayet ettiğini ileri sürmüşlerdir. ${ }^{89}$

Şaraptan sirke imaline cevaz verenler ise şarabın kendiliğinden sirkeleşmesi ile müdahale sonucu sirkeleşmesi arasında herhangi bir farkın bulunmadığını söylemişlerdir. Bahsi geçen hadislerde yasaklanan hususun şarabın sirke gibi katık olarak kullanılmasına ilişkin olduğunu, yoksa şarabı sirkeye dönüştürmenin veya bu şekildeki sirkeden faydalanmanın haram kılınmadığını ifade etmişlerdir. Ayrıca rivayetlerin o anlamları taşıdığı varsayılsa bile şarabın haram kılındığı ilk dönemlerde Hz. Peygamber'in insanları şarap içme yasağına uymalarını kolaylaştırmak amacıyla şarabı sirkeye dönüştürmekten menetmiş olabileceğini söyleyerek hadisler arasındaki tenakuzu gidermeye çalışmışlardır. ${ }^{90}$

Görüldüğü üzere fukahâ şarabın kendiliğinden sirkeye dönüşmesi örneğinde istihâleyi, ittifakla temizleyici bir yöntem olarak kabul etmiştir. $\mathrm{Bu}$ olayda aslen temiz olan bir şeyin kirlendikten sonra aslî özelliklerine tekrar kavuşması söz konusudur. Buna göre şarap gibi sonradan pis hale gelen şeylerde de kendiliğinden vuku bulan istihâlenin temizleyici olduğunu söylemek mümkündür. Nitekim fakihler kirlenen suyun kendiliğinden istihâle geçirmesiyle temizleneceğini söylemişlerdir. ${ }^{91}$

Hanefîler ile Mâlikîler'in şarabın müdahale ile sirkeleşmesinin hükmü konusunda görüş oluştururken şaraptan sirke imalini meneden rivayetleri, haber-i vâhidi temel fikhî kurallara arz etmeye ilişkin usûlleri ${ }^{92}$ doğrultusunda değerlendirdikleri anlaşılmaktadır. Onlar, şarabın sirkeleşmesi durumunda helâl hale geleceğini bildiren rivayetlerden "bir maddenin temel yapısı değişince hükmü de değişir" şeklinde genel bir kural oluşturmuşlar ve necâsetin temel özelliklerini kaybedip başka bir maddeye dönüşmesiyle temiz hükmünü alacağını söylemişlerdir. ${ }^{93} \mathrm{Bu}$ genel kurala muarız gibi görünen rivayetleri ise tevil yoluna

\footnotetext{
${ }^{88}$ Mâverdî, el-Hâvi'l-kebîr, 6: 113; Nevevî, el-Mecmû́, 2: 575-6.

${ }^{89}$ Mâverdî, el-Hâvi'l-kebîr, 6: 114-5; İbn Kudâme, el-Muğnî, 9: 173.

90 Serahsî, el-Mebsût, 24: 24; Kâsânî, Bedâi u's'sanâi', 5: 114.

${ }^{91}$ Buhûtî, Keşşâfü'l-kınâc', 1: 187.

92 Ebû Bekr Ahmed b. Alî er-Râzî el-Cessâs, el-Fusûl fi'l-usûl (Kuveyt: Vizâratü'l-evkâf ve'ş-şuûni'lİslâmiyye, 1985), 3: 128.

93 "Kâsânî,

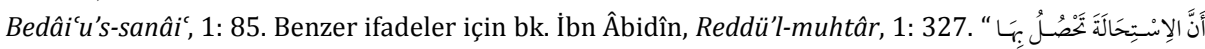
الطََُّهارَةُ" Nefrâvî, el-Fevâkihü'd-devânî, 2: 288.
} 
gitmişlerdir. Şâfiîler ile Hanbelîler ise şaraba müdahale ederek sirke üretmeye ruhsat vermeyen rivayetleri sıhhat bakımından daha güçlü bulmuş ve o doğrultuda görüş geliştirmişlerdir. Onlar bu görüşü ortaya koyarken müdahale neticesinde şarapta meydana gelen değişimi yok saymamışlardır; ancak söz konusu rivayetleri esas aldıklarından dolayı bu değişimi şarabın temizliği için yeterli görmemişlerdir. İki tarafın görüşleri dayanakları ile birlikte karşılaştırıldığında, Hanefîler ile Mâlikîler'in görüşünün usûlleri açısından tutarlı, diğer tarafın ise istidlâlde bulunduğu rivayetlerin daha sağlam olduğu görülmektedir. Ancak yukarıda ifade edildiği gibi bu rivayetlerin şarabın haram kılındığı ilk dönemlerde insanların yasağa uyumlarını kolaylaştırmak üzere varid olduğu dikkate alınırsa Hanefîler ile Mâlikîler'in tercih ettiği görüşün daha isabetli olduğunu söylemek mümkündür. ${ }^{94}$

Mezheplerin istihâle konusundaki bu yaklaşımlarının yansıdığı konulardan biri de içine pislik düșen yağdan olușturulan sabunun temizliği meselesidir. Hanefîler, istihâleyi hüküm değiştirici bir yöntem olarak kabul ettikleri için yağın sabuna dönüşmekle birlikte temiz hale geldiğini ve bu yoldan elde edilen sabunun temizlikte kullanılabileceğini dolayısıyla da alınıp satılmasının caiz olduğunu söylemişlerdir. ${ }^{95}$ Şâfiîler, Hanbelîler ile bazı Mâlikîler ise müteneccis yağı sabuna dönüştürmenin, sabunun necisliğini ortadan kaldırmadığını ${ }^{96}$ ve dolayısıyla bu tür sabunları satışa konu etmenin caiz olmadığını ileri sürmüşlerdir. Ancak Şâfiîler ile Mâlikîler faydasını göz önünde bulundurarak mevzubahis sabunun temizlikte kullanılmasına cevaz vermişlerdir. ${ }^{97}$

\subsection{Aslı Necis Olup İstihâleye Uğrayan Şeylerden Faydalanmak}

İstihâlenin aslı necis olan şeyleri temizlemesi konusunda iki farklı yaklaşım bulunmaktadır. Şarabın ister müdahale sonucu, ister tabii süreci içinde olsun istihâle geçirmesiyle temiz ve helâl hale geldiğini düşünenlerin ortaya koyduğu birinci yaklaşıma göre istihâleye uğrayan her necis madde temiz olur. Bu görüşün öncülüğünü yapan İmam Muhammed'e göre necis madde istihâleyle hem öz hem de vasıf bakımından değişime uğramakta ve dolayısıyla yeni bir madde ortaya çıkmaktadır. Maddenin yapısı ve özellikleri değiştiğine göre hükmü de değişmelidir. Hanefîler'de mezhep görüşü haline gelen bu yaklaşıma göre bir domuz $^{98}$ veya köpek tuz gölüne düşüp tuzlaşınca, ${ }^{99}$ insan pisliği atește yanıp kül

${ }^{94} \mathrm{Bu}$ görüş, günümüzde bazı araştırmacılar tarafından da tercih edilmektedir. Bk. Yâsin b. Nâsır elHatîb, “Bahsun Muhkem: el-İstihâletü ve ahkâmuhâ fi'l-fikhi'l-İslâmî”, Mecelletü'l-'Adl 15/17 (2013): 98-99.

95 Burhânüddîn, el-Muhît, 1: 191; İbn Nüceym, el-Bahru'r-Râik, 1:239; İbn Âbidîn, Reddü'l-muhtâr, 1: 316.

96 Buhûtî, Keșşâfü'l-kınâc, 1: 186; Mâverdî, el-Hâvi'l-kebîr, 15: 158-9.

97 İbn Battâl, Șerhu Sahîhi'l-Buhârî, 5: 451; İbn Rüșd, Bidâyetü'l-müctehid, 538; Nevevî, el-Mecmû', 4: 448; Şirbînî, Mugni'l-muhtâc, 1: 586. Mâlikîler ayrıca bu tür sabunlarla yıkanan giysilerin sabunun izi kalmayıncaya kadar temiz suyla yıkanması gerektiğini özellikle belirtmișlerdir. Hattâb er-Ruaynî, Mevâhibü'l-celîl, 1: 117; Nefrâvî, el-Fevâkihü'd-devânî, 1: 389.

98 İbn Âbidîn, Reddü'l-muhtâr, 1: 326.

99 Günümüzde kimya verilerine dayanılarak organik maddelerin tuzun içinde kaybolmadığı ifade edilmektedir (Bk. Candan, “Doğrulanabilirlik İlkesi Açısından Fıkıh Literatüründeki İstihâle Örnekleri 
haline gelince, necis olan bir şey toprağın altında eserini tamamen kaybedince ${ }^{100}$ ve köpek sabun kazanına düşüp sabuna dönüşünce temiz olur. Ancak susamın yağ, sütün peynir, buğdayın un, unun ekmek olması gibi örneklerde gerçek bir dönüşüm gerçekleşmemektedir. Dolayısıyla bunlardaki değişim, tathîr için yeterli değildir. ${ }^{101}$ İçine necâset düşen sütten peynir yapılırken kimyasal aktivite söz konusu olduğu halde ${ }^{102}$ Hanefîler, bunu temizleyici bir istihâle saymadıklarına göre onlar, maddenin ismi ve vasıflarının yanı sıra özünde de gerçekleşen değişimi, temizleyici bir yöntem olarak kabul etmișlerdir. Öte yandan bu hadiseye böyle bir hükmün bağlanmasında söz konusu sütteki necâsetin istihâle geçirmemiş olması da etkilidir. Örneğin içine idrar dökülmüş bir süt yoğurt yapılınca istihâle sadece sütte gerçekleşmekte, idrar kısmı ise olduğu gibi yoğurdun içinde kalmaya devam etmektedir. ${ }^{103}$ Buna göre başka bir maddeye dönüşen necis bir şeyin temiz hükmünü alabilmesi için bütün cüzleri ile istihâleye uğramış olması gerekmektedir. Böyle bir işlem, kimya jargonuyla maddenin bir bütün olarak kimyasal köklere ayrılması ve ardından molekül yapısının öncekinden farklı bir maddeye dönüșmesi faaliyetidir. Bu yöntemle meydana gelen maddeyi eski haline döndürmek imkânsız olduğu gibi bunda öncekinden izler de bulunmamaktadır. ${ }^{104}$

Hanefîler'in öncülük ettiği bu görüş Zâhirîler ${ }^{105}$ ile bazı Mâlikîler tarafından da kabul görmüştür. ${ }^{106}$ İbn Hazm bu anlayış doğrultusunda, cellâle hayvanın yediği pisliğin etinden bir parçaya dönüştüğünü, dolayısıyla etinin temizlenmesi için hayvanı kesmeden önce belli bir müddet temiz şeylerle beslemenin gerekli olmadığını söylemiştir. ${ }^{107}$

ve Güncel Bazı Tespitler", 122). Bu bilgi esas alınırsa, fıkıh kitaplarında tuzlaya düșen bir hayvanın zamanla tuza dönüşeceğine ilişkin anlatımların varsayım babından olduğunu kabul etmek gerekir.

100 Kâsânî, Bedâi' u's-sanâic, 1: 85; Burhânüddîn, el-Muhît, 1: 190; İbn Nüceym, el-Bahru'r-Râik, 1: 239.

101 İbn Âbidîn, Reddü'l-muhtâr, 1: 316.

102 fenbilimi.net, "Fiziksel ve Kimyasal Değişim”, erişim: 1 Mart 2017, http://fenbilimi.net/maddenintanecikli-yapisi/fiziksel-ve-kimyasal-degisim.html.

103 Yahya Şenol, Kur'ân'a Göre Hayvansal Gıdalarda Helâllik Ölçüleri (Doktora Tezi, İstanbul Üniversitesi, 2013), 76.

${ }^{104}$ Karadâğî - Muhammedî, Flkhü'l-kadâya't-tıbbiyyeti'l-mu'âsıra, 205; Yûsî el-Hevârî, "el-İstihâle beyne ilmi'l-fıkh ve ilmi'l-kimyâ", Mecelletü's-sırât11/19 (2009): 104; Orhan Çeker, "İstihale”, 1. Ulusal Helâl ve Sağlıklı Gıda Kongresi (Ankara, 19-20 Kasım 2011), ed. Fatih Gültekin (b.y.: y.y., 2011), 20; fenbilimi.net, "Fiziksel ve Kimyasal Değișim".

105 İbn Hazm, el-Muhallâ, 1: 143.

106 Hattâb er-Ruaynî, Mevâhibü'l-celîl, 1: 97.

107 el-Muhallâ, 6: 110. Cellâle, yediğinin çoğu pislik olan veya yediği pislikten dolayı eti, teri kokan koyun, sığır, deve ve tavuk gibi eti yenen hayvanlara verilen isimdir. Hanefîler ve Mâlikîler de cellâle hayvanın yediği pisliğin ete dönüşmesi sonucunda temizlendiğini kabul etmekle birlikte etteki kokunun giderilmesi için hayvanın bir müddet temiz șeylerle beslenmesini gerekli görmüșlerdir (Serahsî, el-Mebsût, XI, 255-256; Kâsânî, Bedâiu's-sanâî, 5: 39-40; Hattâb er-Ruaynî, Mevâhibü'l-celîl, 1: 97). Hanbelîler, istihâleyi temizleyici bir yöntem olarak görmediklerinden necis maddeleri tüketen hayvanın etinin de necis olacağını söylemişlerdir (İbn Kudâme, el-Muğnî, 9: 414). Şâfiîler'e göre hayvanın yediği necâset, sindirim kanallarından aşağı iner ve etine karışmaz; ancak kokusu etine

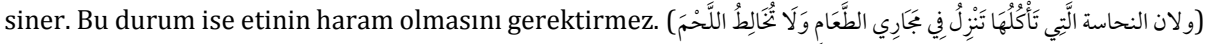
Nevevî, el-Mecmû', 9: 30. Günümüzde yapılan araştırmalar, geviş getiren hayvanların yediği pis şeylerin, boşaltım sisteminden doğrudan dışarı atıldığını göstermektedir. (03-05 Kasım 2017 tarihinde Yıldırım Beyazıt Üniversitesi Yerleşkesi'nde gerçekleştirilen 4. Uluslararası Helâl ve Sağlıklı 
İkinci yaklaşıma göre ise "ayn"ı (aslı) necis olan maddeler istihâle ile temiz hale gelemez. Bu yaklaşım başta Şâfiî ve Hanbelî mezhepleri olmak üzere bazı Mâlikî fakihler ${ }^{108}$ ile Ebû Yusuf ${ }^{109}$ tarafından benimsenmiştir. Onlar, "ayn"ı necis olan şeyleri, aslı temiz olup sonradan oluşan "sekr" vasfı sebebiyle necisleșen şaraba kıyaslamayı doğru bulmamışlardır. Ayrıca şarabın müdahale edilerek sirkeye dönüştürülmesini meneden rivayetleri, şarap haricindeki necis şeyler için de geçerli saymışlardır. ${ }^{110}$ Onlara göre istihâlenin temizleyici fonksiyonu olsaydı, Hz. Peygamber necis şeyleri tüketen cellâlenin etini yemekten ve sütünü içmekten sakındırmazdı. ${ }^{111} \mathrm{Bu}$ görüşte olanlar necâsetin yanıp kül olmasıyla necislikten çıkmadığını ve yakılan necis maddelerden çıkan dumanın da necis olduğunu söylemişlerdir. ${ }^{112}$ Yine bir köpeğin veya meytenin tuz gölüne düşüp tuzlaşmasıyla yahut sabun kazanında sabuna dönüşmesiyle temiz hale gelemeyeceğini düşünmüşlerdir. ${ }^{113}$ Bununla birlikte Şâfiîler ve Hanbelîler ilgili rivayetlerde hoş koku olarak nitelenmiş olmasına dayanarak ${ }^{114}$ ceylan kanından elde edilen miski istisna edip, bunun temiz olduğunu söylemişlerdir. ${ }^{115}$

$\mathrm{Bu}$ konudaki örneklerden biri de necis suyla sulanan ve hayvan tersiyle gübrelenen ziraî ürünlerin hükmüne ilișkindir. Hanefîler ve Mâlikîler necâsetin bitkide istihâleye uğradığını belirterek bu şekilde yetiștirilen ürünlerin helâl olduğunu söylemişlerdir. ${ }^{116}$ Hanbelîler ise bitkinin necâsetle büyüdüğünü ve necâsetin bitkiye dönüşmesi esnasında necisliğinin ortadan kalkmadığını söyleyerek ortaya çıkan ürünün necis olduğunu ileri sürmüşlerdir. Fakat onlara göre, şayet bu tür ürünler daha sonra temiz suyla sulanırsa temiz yemle beslenen cellâle gibi helâl hale gelir.117 Şâfiîler uygulamanın yaygınlığını ve necâsetin izinin

Gıda Kongresi'nin 4. Oturumunda bu bilgi verilmiş ve herhangi bir itirazla karşılaşılmamıştır.) Bu veri dikkate alınırsa Şâfiîler'e ait görüşün daha isabetli olduğunu söylemek gerekir.

108 Karâfî, ez-Zahîra, 1: 189.

109 Kâsânî, Bedâi'u's-sanâi', 1: 85.

110 Mâverdî, el-Hâvi'l-kebîr, 6: 112-115; İbn Kudâme, el-Muğnî, 1: 53; Nevevî, el-Mecmû', 2: 573-579; Şirbînî, Mugni'l-muhtâc, 1: 236-237; Buhûtî, Keşşâfü'l-kınâc', 1: 187.

111 Buhûtî, Keșşâfü'l-kınâ', 1: 29.

112 Mâverdî, el-Hâvi'l-kebîr, 15: 161; Nevevî, el-Mecmûc, 9: 238; Buhûtî, Keșşâfü'l-kınâ', 1: 186. Ancak necis șeyin dumanı az ise sakınmanın zorluğundan dolayı hoș görülür. Şirbînî, Mugni'l-muhtâc, 1: 236.

113 Nevevî, el-Mecmûc', 2: 579; Remlî, Nihâyetü'l-muhtâc, 1: 247; İbn Kudâme, el-Muğnî, 1: 53; Buhûtî, Keşşâfü'l-kınấc, 1: 187.

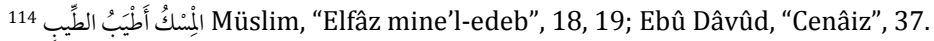

115 Mâverdî, el-Hâvî'l-kebîr, 5: 335; Remlî, Nihâyetü'l-muhtâc, 1: 241; Buhûtî, Keșşâfü'l-kınâc, 1: 191.

116 Hattâb er-Ruaynî, Mevâhibü'l-celîl, 1: 97; Nefrâvî, el-Fevâkihü'd-devânî, 1: 389; İbn Âbidîn, Reddü'lmuhtâr, 6: 341. İmâm Mâlik'in bu şekildeki sulamaya cevaz vermediği de nakledilmiștir. Karâfî, ezZahîra, 1: 188.

117 İbn Kudâme, el-Muğnî, 9: 414; Buhûtî, Keşşâfü'l-kınâc, 6: 194; İbn Teymiyye, el-Muharrâr, 2: 190. Fukahâ, kendi dönemlerindeki malumat doğrultusunda necis suyun ve gübrenin bitkide istihâlesinden bahsetmişse de günümüzde biyokimyanın verilerine göre bu anlamda bir istihâle gerçekleşmemekte, söz konusu maddeler toprakta istihâleye uğradıktan sonra bitkiler tarafından imtisas edilmektedir. Bitkiler sadece inorganik madde ile beslendiği için hayvan atıkları gibi organik maddeler, toprak tarafından parçalanarak inorganik maddeye dönüştürüldükten sonra bitkiler tarafından kullanılır. Dolayısıyla bitkiler toprağa atılan hayvan gübresinden sadece istihâle geçiren kısmını kullanır. Çayıroğlu, İslam Hukuku'na Göre Helâl Gıda Sorunu, 207-8. 
üründe görünmemesini gerekçe göstererek genel yaklaşımlarından vazgeçip bu şekilde ürün yetiştirmenin mubah olduğunu belirtmişlerdir. ${ }^{118}$

Görüldüğü üzere nassların zahiriyle amel etmeye ağırlık veren Şafiîler ile Hanbelîler, meseleyi ilgili hadisler çerçevesinde ele almış ve rivayetlerde bahsi geçmeyen istihâlelerin, nesnelerin hükmünü değiştirmede etkili olmadığı görüşünü benimsemişlerdir. Buna karşılık ehl-i rey olarak bilinen Hanefîler, kıyas delilini kullanarak nasslarda yer alan istihâle hâdiselerinin çerçevesini genişletmiş ve istihâlenin bütün necis maddelerin hükmüne tesir edeceğini söylemişlerdir. ${ }^{119}$

İstihâle ilgili sözü edilen iki yaklaşım günümüzde de varlığını devam ettirmektedir. İstihâlenin sonradan necis hale gelen şeylerde olduğu gibi aslen necis olan şeylerde de yapısal değişikliğe yol açtığı realitesi göz önünde bulundurulursa hüküm değiştirici işlevinin bu çeşit necâset için de geçerli olması gerektiği düşünülebilir. Ancak necâsetler arasında ayırım yapılmadığı takdirde nasslarda mutlak olarak haram kılınmış şeylere, istihâleye uğradıktan sonra helâl hükmünü vermek gibi bir sorun ortaya çlkmaktadır. Örneğin istihâleye bu fonksiyon yüklenildiği takdirde domuz eti ve yağının istihâle ile başka bir maddeye dönüștürülmesi durumunda helâl hükmünü alması söz konusu olacaktır. Nitekim günümüz araştırmacılarından bazıları istihâleye uğrayan domuz türevlerinin helâl olduğunu söylemektedirler. ${ }^{120}$ Oysa domuz eti ve yağının haramlığı, kat'î delillerle sabit olduğundan bunları faydalanılabilir hale getirmek nassa muhalif bir girişim gibi görünmektedir. Bu durumda istihâle geçiren domuz eti ve yağının farklı bir maddeye dönüștüğünü, dolayısıyla yeni maddeden faydalanmanın domuz yasağı dışında kaldığı düşünülebilir. Ancak yukarıda paylaştığımız hadiste görüldüğü üzere Hz. Peygamber'in, yahudilerin hayvan yağını eritip satmalarının, haklarındaki yağdan faydalanma yasağını dolaylı da olsa çiğnemek olarak yorumlaması, istihâleyle başkalaştırıldıktan sonra da domuz eti ve yağından yararlanmanın caiz olmadığını göstermektedir. Meseleye bu açıdan bakınca, istihâlenin hükümde etkisiz olduğuna ilişkin yaklaşımın daha isabetli olduğu düşünülebilir. Fakat nasslarda mutlak olarak haram kılınmamış veya bahsi geçmeyen necis şeylerde bu sorun söz konusu değildir. Buna göre bu tür şeylerin istihâle geçirdikten sonraki varlıklarından faydalanmak nasslara aykırı bir tutum gibi görünmemektedir.

Öte yandan fıkıh müdevvenatındaki istihâle temelli fetvaların "teysîr" ve "belvâ" nitelikli ara çözümlerden ibaret olduğu ve normal şartlarda "ayn"ı necis maddelerin istihâle ile temizlenemeyeceği de söylenmektedir. ${ }^{121}$ İstihâlenin

\footnotetext{
118 Mâverdî, el-Hâvi'l-kebîr, 15: 162; Nevevî, el-Mecmûc, 9: 29; Şirbînî, Mugni'l-muhtâc, 6: 156.

119 Çayıroğlu, İslam Hukuku'na Göre Helâl Gıda Sorunu, 256.

120 Karadâĝî - Muhammedî, Fıkhü'l-kadâya't-tıbbiyyeti'l-mu'âsıra, 217; Hatîb, "Bahsun Muhkem: elİstihâletü ve ahkâmuhâ fi'l-fikhi'l-İslâmî", 120; Mecme'u'l-fıkhi'l-İslâmî, "el-İstihâle ve'l-istihlâk ve'lmevâddü'l-idâfiyye fi'l-gıdâ ve'd-devâ" (4/21) 198, erişim: 23 Temmuz 2018, http://www.iifaaifi.org/2392.html.; Avrupa Fetva ve Araştırma Kurulu, “23. Olağan Dönem Kararları - el-İ́stihâle ve'listihlâk", 3/23, erişim: 23 Temmuz 2018, www.e-cfr.org/بشأن-الاستحالة-و الاستهلاك/.

121 Kâşif Hamdi Okur, "İslam Hukuku Açısından Helâl ve Haram Olan Gıdalar ve Bazı Güncel Meseleler”, VI. İslâm Hukuku Anabilim Dalı Koordinasyon Toplantısı ve İslâm Fıkhı Açısından Helâl Gıda Sempozyumu, ed. Ali Kaya (Bursa: Emin Yayınları, 2009), 56.
} 
sıkıntılı durumunda kolaylık sağlayan yönü, içine pislik düşmüş zeytinyağı örneğinde açıkça kendini göstermektedir. Bu yağın sabuna dönüştürülmesi durumunda temizlendiğini kabul etmek, yağın değerlendirilmesine imkân sağlamaktadır. Nitekim Hanefîler'den de bazı fakihler, istihâlenin tathîr işlevinden bahsederken "belvâ"yı bir gerekçe olarak ileri sürmüşlerdir. ${ }^{122}$ Ancak konuyla ilgili açıklamaları incelendiğinde Hanefîler'in istihâleyi aslî bir temizleme yöntemi olarak gördükleri anlaşılmaktadır. İstihâlenin meşruiyetini anlatırken şarabın sirkeleșmesiyle, "nütfe"nin ise "mudğa" aşamasına gelmesiyle temiz hale gelişi gibi örnekler vererek bir maddenin aslının değişmesiyle, ona bağlanan hükmün de değişmesi gerektiğini ifade etmiş olmaları ${ }^{123}$ da bu kanaatte olduklarını göstermektedir.

Bazı araştırmacılar ise sağlığı korumanın dinin temel ilkelerinden oluşunu esas alarak, günümüz teknolojik imkânları dâhilinde laboratuvarlarda yapılacak inceleme sonucuna göre istihâlenin hükmünü belirlemek gerektiğini ifade etmişlerdir. ${ }^{124} \mathrm{Bu}$ teklif de makul olmakla birlikte yukarıda da değindiğimiz gibi nasslarda faydalanılması mutlak olarak haram kılınan "ayn"ı necis şeyleri bundan istisna etmek gerekmektedir. Zira sağlı̆̆ korumak temel ilkelerden olmakla birlikte haramların konuluş amacı bundan ibaret değildir. Bir șeyin haram kılınmış olmasının imtihan ve kimlik inşası gibi boyutları da bulunabilmektedir. ${ }^{125}$ Buna göre istihâlenin aslen necis olan șeylere etkisi konusunda nasslarda mutlak olarak haram kılınan maddeleri diğerlerinden farklı değerlendirmek gerekmektedir. Haramlığının mutlak olduğuna dair hakkında nassî delil bulunmayan veya nasslarda bahsi geçmeyen necis şeylerde meydana gelen istihâlenin ise ortaya çıkan yeni maddenin insan sağlığına etkisine göre hükme bağlamanın isabetli olacağını söylemek mümkündür. $\mathrm{Bu}$ yaklaşım, nasslarda bildirilen teklifi hükümlerin değiștirilemeyeceğine (el-Ấrâf 7/32; Yûnus 10/59; en-Nalh 16/116) ilişkin ilkeyle de uyumluluk arz etmektedir.

\section{Sonuç}

İnsanoğlu necis şeylerden fitratı itibariyle rahatsızlık duyar ve dolayısıyla tükettiği/kullandığı maddelere necâseti bulaștırmamaya özen gösterir. Ancak bununla birlikte hayvan tersini yakacak ve gübre olarak kullanma örneğinde olduğu gibi geçmişten bugüne ihtiyaç duyuldukça necis şeylerden faydalanmaktan da imtina etmemiștir. Günümüzde de teknolojik imkânlardan yararlanılarak domuz kemiği ve derisinden jelatin elde etmek gibi necis bazı şeyler tüketim/kullanım malzemesine dönüștürülmektedir. Necis maddelerden bu

\footnotetext{
122 İbn Âbidîn, Reddü'l-muhtâr, 1: 316.

123 İbn Nüceym, el-Bahru'r-Râik, 1: 239; İbn Âbidîn, Reddü'l-muhtâr, 1: 327.

${ }^{124}$ Hamdi Döndüren, "Kur'ân ve Sünnet'e Göre Helâl-Haram Gıdalar ve Kimyasal Değișim” (İstihâle ve Tegayyür), VI. İslâm Hukuku Anabilim Dalı Koordinasyon Toplantısı ve İslâm Fıkhı Açısından Helâl Gıda Sempozyumu, ed. Ali Kaya (Bursa: Emin Yayınları, 2009), 67; Mehmet Selim Aslan, "İslam Hukukuna Göre İstihâle ve İstihlâkın Necis Katkı Maddesi İçeren Gıda, İlaç, Kozmetik ve Temizlik Malzemelerinin Hükmüne Etkisi”, Uluslararası Sosyal Araștırmalar Dergisi 9/43 (Nisan 2016): 2343.

125 Bk. Hüseyin Baysa, "İslâm Borçlar Hukukunda Akdin Konusunu Seçme Özgürlüğünün Kısıtlanmasının Temel Dinamikleri”, İslam Hukuku Araştırmaları Dergisi 23 (Nisan 2014): 160-170.
} 
şekilde faydalanmanın hükmü, fıkıh problemlerinden biri olarak önümüzde durmaktadır. Bu konuda yapılacak araştırmalara katkı sağlamak amacıyla yazılan bu makalede ilgili nasslar ve fukahâ görüşleri değerlendirilmeye tabi tutularak bir neticeye ulaşılmaya çalışılmıştır. Araştırma boyunca elde edilen sonuçları şu şekilde özetlemek mümkündür:

Necis olarak bilinen domuz eti ve yağı, şarap, murdar hayvanın eti ve yağı ile kanın gıda maddesi olarak kullanılması Kur'ân'da haram kılınmıştır. Bu şeylerin ticari akde konu edilmesinin haramlığı, sünnetle sabit olmuştur. İlgili nassları değerlendiren fukahâ, necis şeylerden, nasslarda haram kılınan yöntemlerle faydalanmanın caiz olmadığı hususunda ittifak etmiştir. Murdar hayvan yağını aydınlatma ve gemi yağlama gibi alanlarda kullanmanın hükmü konusunda ise ilgili rivayetlerin farklı yorumlamasına bağlı olarak cumhurun aksine Şâfiîler olumlu bir yaklaşım içinde olmuşlardır. Bununla birlikte fukahâ, satışı nasslarla haram kılınan necis şeyleri ticari akde konu etmenin caiz olmadığı hususunda görüş birliğine varmıştır. Aynı şekilde nasslarda bahsi geçmeyen necis maddelerin insan gıdası olarak kullanılamayacağı, bunun dışındaki alanlarda ise fayda temin edici özelliğinin esas alınarak yararlı şeylerin kullanılabileceği yönünde ittifak etmiştir. Bu tür şeylerin bu amaçlarla ticareti hakkında ise cumhur, nasslarda satışı haram kılınmış necis maddelere kıyasla olumsuz bir yaklaşım sergilerken; Hanefîler, nasslarla yasaklanmamış yönlerinden yararlanmak üzere bunları alıp satmaya cevaz vermişlerdir. Cumhurun bu özellikteki necâsetten yararlanmayı mubah saymasına karşın bunların satışına ruhsat vermemiş olması, tutarsız bir yaklaşım gibi görünmektedir. Hanefîler'in görüşü ise dayanak bakımından daha güçlü olduğu gibi ibâha-i asliye ilkesine de uygunluk arz etmektedir.

İstihâleye uğramış necâsetin hükmü konusunda ise şarabın sirkeye dönüştürülmesine ilişkin rivayetler esas alınmış ve şarabın kendiliğinden sirkeleşmesiyle temiz ve helâl hale geleceği konusunda icmâ edilmiştir. Şarabın müdahale neticesinde istihâle geçirmesi durumunda alacağı hüküm hakkında ise haber-i vâhidin kaynak değerine ilişkin yaklaşımlar doğrultusunda farklı görüşler geliştirilmiştir. Şâfiîler ile Hanbelîler, ilgili rivayetleri esas alarak dişardan müdahale ile sirkeleşen şarabın hükmünü koruduğunu söylerken, Hanefîler, Zâhirîler ve Mâlikîler, bir şeyin aslının ve özelliklerinin değişmesiyle hükmünün de değişeceğini ifade eden bir kural geliștirip, söz konusu rivayetleri o doğrultuda yorumlamış ve şarabın geçireceği kimyasal değişim sonucunda sirkeleşmesiyle artık sirke hükmünü alacağını söylemişlerdir. Şarap haricindeki necis şeylerin istihâle neticesinde alacağı hüküm konusunda da her iki taraf benzer yaklaşımları sergilemiştir. İlgili rivayetler ile fukahânın şarabın kendiliğinden sirkeleşmesiyle temizleneceğine ilişkin ittifakı göz önünde bulundurulduğunda şarap haricindeki müteneccis şeylerin de kendiliğinden istihâleye uğramasıyla temiz olacağını söylemek mümkündür. Müdahale neticesinde meydana gelen istihâlenin etkisi konusunda Şâfiîler ile Hanbelîler'in savunduğu görüş, ilgili rivayetlerin zahiriyle mutabık ise de kimyasal değişimin öncekinden farklı yeni bir maddeyi meydana getiren işlevini göz ardı etmesi açısından problemli gibi görünmektedir. Hanefîler ile Mâlikîler'in istihâlenin bu fonksiyonunu esas alarak her değişim geçiren necis maddenin öncekinden farklı bir hükmü gerektirdiği yönündeki yaklaşımları ise 
nasslarda mutlak olarak haram kılınan necis şeylerden faydalanmanın ruhsatına yol açması açısından sorunlu görünmektedir. Bunun yerine domuz ve şarap gibi hakkında mutlak yasaklayıcı nass bulunan maddelerin dışındaki necis şeylerin, tam bir istihâle geçirmesi sonucunda meydana gelen yeni maddenin öncekinden farklı bir hüküm alacağını söylemek, ilgili nasslar ve realite açısından daha isabetli olabileceğini söylemek mümkündür.

\section{Kaynakça}

Adevî, Ebü'l-Hasan Alî b. Ahmed b. Mükrim. Hâşiyetü'l-Adevî 'alâ Kifâyeti't-tâlibi'r-rabbânî. Beyrut: Dâru'l-fikr, 1994.

Aslan, Mehmet Selim. "İslam Hukukuna Göre İstihâle ve İstihlâkın Necis Katkı Maddesi İçeren Gıda, İlaç, Kozmetik ve Temizlik Malzemelerinin Hükmüne Etkisi”. Uluslararası Sosyal Araștırmalar Dergisi 9/43 (Nisan 2016): 2326-2345.

Baysa, Hüseyin. "Hayvansal Yan Ürünlerin Ticaretinde Helâllik Sorunu". İslam Hukuku Araștırmaları Dergisi 30 (Ekim 2017): 423-437.

Baysa, Hüseyin. "İslâm Borçlar Hukukunda Akdin Konusunu Seçme Özgürlüğünün Kısıtlanmasının Temel Dinamikleri”. Islam Hukuku Araştırmaları Dergisi 23 (Nisan 2014): 157-172.

Beyhakî, Ahmed b. el-Huseyn. es-Sünenü'l-kübrâ. Beyrut: Dâru'l-kütübi'l-ilmiyye, 2003.

Buhârî, Muhammed b. İsmâîl Ebû Abdillâh. el-Câmi'u's-sahîh. Beyrut: Dâru İbn Kesîr, 1987.

Buhûtî, Mansur b. Yunus b. Salahiddîn. Keşşâfü'l-kınâa 'an metni'l-Iknnấ. b.y.: Dâru'l-kütübi'l-ilmiyye, ty.

Burhânüddîn, Ebü'l-Me'âlî Mahmûd el-Buhârî. el-Muhîtu'l-Burhânî fi'l-fikhi'n-Nu'mânî. Beyrut: Dâru'lkütübi'l-ilmiyye, 2004.

Candan, Abdurrahman. "Doğrulanabilirlik İlkesi Açısından Fıkıh Literatüründeki İstihâle Örnekleri ve Güncel Bazı Tespitler". Diyanet Illmî Dergi 53/1 (Ocak Şubat Mart 2017): 103-130.

Cessâs, Ebû Bekr Ahmed b. Alî er-Râzî. Ahkâmü'l-Kur'ân. Beyrut: Dâru'l-kütübi'l-ilmiyye, 1994.

Cessâs, Ebû Bekr Ahmed b. Alî er-Râzî. el-Fusûl fi'l-usûl. Kuveyt: Vizâratü'l-evkâf ve'ş-şuûni'l-İ̀lâmiyye, 1985.

Cezîrî, Abdurrahmân. Kitabü'l-fikh 'ale'l-mezâhibi'l-erbe`a. Beyrut: Dâru'l-kütübi'l-ilmiyye, 2010.

Çayıroğlu, Yüksel. İslam Hukuku'na Göre Helâl Gıda Sorunu. Doktora Tezi, Marmara Üniversitesi, 2013.

Çeker, Orhan. "İstihale". 1. Ulusal Helâl ve Sağlıklı Gıda Kongresi (Ankara, 19-20 Kasım 2011). Ed. Fatih Gültekin. 18-21. b.y.: y.y., 2011.

Dalgın, Nihat. "İslâm Hukukuna Göre Satım Sözleșmesi Açısından Mal Kavramı". Ondokuz Mayıs Üniversitesi Illahiyat Fakültesi Dergisi 11 (1999): 97-127.

Döndüren, Hamdi. "Kur'ân ve Sünnet'e Göre Helâl-Haram Gidalar ve Kimyasal Değişim (İstihâle ve Tegayyür). VI. İslâm Hukuku Anabilim Dalı Koordinasyon Toplantısı ve İslâm Fıkhı Açısından Helâl Gıda Sempozyumu. Ed. Ali Kaya. 59-73. Bursa: Emin Yayınları, 2009.

Ebû Dâvûd, Süleymân b. el-Eş'as b. İshâk es-Sicistânî el-Ezdî. es-Sünen. b.y.: Dâru'r-risâleti'l-âlemiyye, 2009.

Ebû Habîb, Se 'dî. “Hâle”. el-Kâmûsü'l-fikhî luğğâten ve Istılâhen. 105. Dımaşk: Dâru'l-fikr, 1988.

Elgün, Adem. "Şarabın Sirkeye Dönüşümü". 1. Ulusal Helâl ve Sağlıkl Gıda Kongresi (Ankara, 19-20 Kasım 2011). Ed. Fatih Gültekin. 50-58. b.y.: y.y., 2011.

Erdoğan, Mehmet. "İstihâle". Fikıh ve Hukuk Terimleri Sözlüğü. 263. İstanbul: Ensar Neşriyat, 2005.

Fîrûzâbâdî, Ebü't-Tâhir Mecdüddîn Muhammed b. Ya'kûb b. Muhammed. "Neces". el-Kâmûsü'l-muhît. 576. Beyrut: Müessetü'r-risâle, 2005.

Hacak, Hasan. İslam Hukuku'nun Klasik Kaynaklarında Hak Kavramının Analizi. Doktora Tezi, Marmara Üniversitesi, 2000.

Haccâvî, Ebü'n-Necâ Şerefüddîn Mûsâ b. Ahmed b. Mûsâ el-Makdisî. el-İknâc fi fikhi'l-İmâm Ahmed b. Hanbel. Beyrut: Dâru'l-ma'rife, ty.

Hatîb, Yâsin b. Nâsır. "Bahsun Muhkem: el-İstihâletü ve ahkâmuhâ fi'l-fikhi'l-İslâmî”. Mecelletü'l-'Adl 15/17 (2013): 79-120.

Hattâb er-Ruaynî, Ebû Abdillâh Şemsüddîn Muhammed b. Muhammed b. Abdirrahmân. Mevâhibü'l-celîl fí șerhi Muhtasârı Halîl. b.y.: Dâru'l-fikr, 1992.

Hevârî, Yûsî. "el-İstihâle beyne ilmi'l-fikh ve ilmi'l-kimyâ". Mecelletü's-sırât 11/19 (2009): 96-109.

Heyet. “Meyte”. el-Mevsûatü'l-fikhiyyetü'l-Kuveytiyye. 39: 380-394. Kuveyt: Vizâratü'l-evkâf ve'ş-șüûni'lİslâmiyye, 2007.

Heyet. “Necâset". el-Mevsûatü'l-fikhiyyetü'l-Kuveytiyye. 40: 73-117. Kuveyt: Vizâratü'l-evkâf ve'ş-şüûni'lİslâmiyye, 2007. 
Heyet. “Tehavvul”. el-Mevsûatü'l-fikhiyyetü'l-Kuveytiyye. 10: 278-283. Kuveyt: Vizâratü'l-evkâf ve’şşüûni'l-İslâmiyye, 2007.

İbn Âbidîn, Muhammed Emin b. Ömer b. Abdilazîz. Reddü'l-muhtâr ale'd-Dürri'l-muhtâr. Beyrut: Dâru'lfikr, 1992.

İbn Âșûr, Ebû Abdillâh Muhammed et-Tâhir b. Muhammed b. Muhammed eş-Şâzelî. et-Tahrîr ve't-tenvîr. Tunus: ed-Dâru't-Tûnusiyye, 1984.

İbn Battâl, Ebü'l-Hasen Alî b. Halef b. Abdilmelik el-Bekrî el-Kurtubî. Şerhu Sahîhi'l-Buhârî. Riyad: Mektebetü'r-rüșd, 2003.

İbn Hacer, Ebü'l-Fazl Şihâbüddîn Ahmed b. Alî b. Muhammed el-Askalânî. Fethu'l-bârî bi-șerhi Sahîhi'lBuhârî. Beyrut: Dâru'l-ma'rife, 1379.

İbn Hazm, Ebû Muhammed Alî b. Ahmed b. Saîd el-Endelüsî el-Kurtubî. el-Muhallâ bi'l-âsâr. Beyrut: Dâru'l-fikr, ty.

İbn Kudâme, Ebû Muhammed Abdullah b. Ahmed el-Makdisî. el-Muğnî. b.y.: Mektebetü'l-Kahire, 1968.

İbn Mâce, Ebû Abdillâh Muhammed b. Yezîd el-Kazvînî. es-Sünen. Beyrut: Dâru'l-fikr, ty.

İbn Manzûr, Ebü'l-Fazl Cemâlüddîn Muhammed b. Mükerrem b. Alî b. Ahmed el-Ensârî. "Ncs". Lisânü’l'Arab. 6: 226-227. Beyrut: Dâru sâder, 1414h.

İbn Manzûr, Ebü'l-Fazl Cemâlüddîn Muhammed b. Mükerrem b. Alî b. Ahmed el-Ensârî. "Hvl”. Lisânü'l'Arab. 11: 185-195. Beyrut: Dâru sâder, 1414h.

İbn Nüceym, Zeynüddîn b. İbrâhîm. el-Bahru'r-râik şerhu Kenzi'd-dekâik. b.y.: Dâru'l-kütübi'l-İslâmî, ty.

İbn Nüceym, Zeynüddîn b. İbrâhîm. el-Eşbâh ve'n-nezâir. Beyrut: el-Mektebetü'l-asriyye, 2011.

İbn Rüşd, Ebü'l-Velîd Muhammed b. Ahmed el-Kurtubî. Bidâyetü'l-müctehid ve nihâyetü'l-muktesid. Beyrut: Dâru'l-kütübi'l-ilmiyye, 2010.

İbn Teymiyye, Ebü'l-Berekât Mecdüddîn Abdüsselâm b. Abdillâh b. el-Hadır el-Harrânî. el-Muharrâr fi'lfikh alâ mezhebi'l-Imâm Ahmed b. Hanbel. Riyad: Mektebetü'l-meârif, 1984.

Kal'acî, Muhammed Ravvâs - Hâmid Sâdık Kanîbî. "Necâset". Mu'cemü luğğati'l-fukahâ. 475. Beyrut: Dâru'n-nefâis, 1988.

Karadâğî, Alî Muhyiddîn - Muhammedî Alî Yûsuf. Fıkhü'l-kadâya't-tıbbiyyeti'l-mu'âsıra. Beyrut: Dâru'lbeşâiri'l-İslâmiyye, 2006.

Karâfî, Ebü'l-Abbâs Şihâbüddîn Ahmed b. İdrîs. ez-Zahîra. Beyrut: Dâru'l-garbi'l-İslâmî, 1994.

Kâsânî, Alâüddîn Ebû Bekir b. Mes'ûd. Bedâi'u's-sanâi ' fì tertîbi'ş-şerâi'. Beyrut: Dâru'l-kütübi'l-ilmiyye, 1986.

Kastalânî, Ahmed b. Muhammed b. Ebi Bekr. İşâdü's-sârî li şerhi Sahîhi'l-Buhârî. Mısır: el-Matbaa'tü'lkübrâ el-emîriyye, $1323 \mathrm{~h}$.

Kurtubî, Ebû Abdillâh Muhammed b. Ahmed. el-Câmiu' li-ahkâmi'l-Kur'ân. Kahire: Dâru'l-kütübi'lMisriyye, 1964.

Mâverdî, Ebü'l-Hasen Alî b. Muhammed b. Habîb el-Basrî. el-Hâvi'l-kebîr. Beyrut: Dâru'l-kütübi'l-ilmiyye, 1999.

Mevsılî, Abdullah b. Mahmûd b. Mevdûd Mecdüddîn Ebü'l-Fadl. el-İhtiyâr li ta'lîli'l-Muhtâr. Kahire: Matba'atü'l-Halebî, 1937.

Müslim, Ebü'l-Huseyn b. el-Haccâc b. Müslim el-Kușeyrî. el-Câmi'u's-sahîh. Beyrut: Dâru ihyâi't-türâsi'lArabî, ty.

Nefrâvî, Ahmed b. Guneym b. Sâlim Şihâbiddîn en- el-Ezherî. el-Fevâkihü'd-devânî 'alâ Risâleti İbn Ebî Zeyd el-Kayravânî. b.y.: Dâru'l-fikr, 1995.

Nesâî, Ebû Abdirrahmân Ahmed b. Şuayb b. Alî. el-Muctebâ mine's-sünen. Haleb: Mektebü matbû'âti'lİslâmiyye, 1986.

Nevevî, Ebû Zekeriya Muhyiddîn b. Yahya b. Șeref. el-Mecmûcșerhu'l-Mühezzeb. b.y.: Dâru'l-fikr, ty.

Nevevî, Ebû Zekeriyyâ Muhyiddîn b. Yahya b. Şeref. el-Minhâc şerhu Sahîhi Müslim. Beyrut: Dâru ihyâi'ttürâsi'l-Arabî, 1392h.

Okur, Kâşif Hamdi. "İslam Hukuku Açısından Helâl ve Haram Olan Gıdalar ve Bazı Güncel Meseleler”. VI. İslâm Hukuku Anabilim Dalı Koordinasyon Toplantısı ve İslâm Fıkhı Açısından Helâl Gıda Sempozyumu. Ed. Ali Kaya. 23-57. Bursa: Emin Yayınları, 2009.

Ögüt, Salim. "Tahâret". Türkiye Diyanet Vakfı İslâm Ansiklopedisi. 39: 382-385. Ankara: TDV Yayınları, 2010.

Remlî, Ebü'l-Abbâs Şihâbüddîn Ahmed b. Ahmed b. Hamza. Nihâyetü'l-muhtâc ilâ şehi'l-Minhâc. Beyrut: Dâru'l-fikr, 1984.

Salâheyn, Abdülmecîd Mahmûd. Ahkâmü'n-necâsât fi'l-fikhi'l-íslâmî. Cidde: Dâru'l-Muctema', 1991.

Serahsî, Muhammed b. Ahmed Şemsü'l-Eimme. el-Mebsût. Beyrut: Dâru'l-márife, 1993.

Şâfiî, Ebû Abdillâh Muhammed b. İdrîs b. Abbâs. el-Ümm. Beyrut: Dâru'l-fikr, 1990.

Şenol, Yahya. Kur'ân'a Göre Hayvansal Gıdalarda Helâllik Ölçüleri. Doktora Tezi, İstanbul Üniversitesi, 2013. 
Şevkânî, Muhammed b. Ali b. Muhammed. Neylü'l-evtâr şerhu Münteka'l-ahbâr. Lübnan: Beytü'l-efkâri'ddüveliyye, 2004.

Şirbînî, Şemsüddin Muhammed b. Ahmed el-Hatîb. Mugni'l-muhtâc ilâ ma rifeti meânî elfâzi'l-Minhâc. b.y.: Dâru'l-kütübi'l-ilmiyye, 1994.

Tahâvî, Ebû Ca'fer Ahmed b. Muhammed b. Selâme el-Ezdî el-Hacrî el-Mısrî. Şerhu me'âni'l-âsâr. Beyrut: Dâru'l-kütübi'l-ilmiyye, 1399h.

Tirmizî, Ebû Îsâ Muhammed b. Îsâ b. Sevre. el-Câmi'u'l-kebîr. Beyrut: Dâru'l-garbi'l-Arabî, 1998.

Wensinck, Arent Jan, Theodorus Willem Juynboll ve Josef Horovitz. "Ncs". el-Mu'cemü'l-müfehres lielfâzi'l-hadîsi'n-nebevî. 6: 361. Leiden: Mektebetü Brill, 1936-1969.

Yalçın, İsmail. "Fıkıhta Haram Hayvanları Belirleme Sorunu", İslam Hukuku Araştırmaları Dergisi 24 (Ekim 2014): 329-345.

Yücel, İrfan. "İstihale-Müzakereler”. Güncel Dini Meseleler İstişare Toplantısı IV Günümüzde Helâl Gıda (Afyonkarahisar, 26-28 Kasım 2011). Ed. yk. 179. Ankara: Diyanet İşleri Başkanlı̆̆ı Yayınları, 2012.

Avrupa Fetva ve Araștırma Kurulu. “23. Olağan Dönem Kararları - el-İstihâle ve'l-istihlâk”. Erişim: 23 Temmuz 2018. www.e-cfr.org/بشأن-الاستحالة-ووالاستهلاك/.

fenbilimi.net. "Fiziksel ve Kimyasal Değișim”. Erișim: 1 Mart 2017. http://fenbilimi.net/maddenintanecikli-yapisi/fiziksel-ve-kimyasal-degisim.html.

hayatisaglik.com. "Normal idrarın özellikleri nelerdir?”. Erişim: 23 Ağustos 2017. http://www.hayatisaglik.com/laboratuvar/normal-idrarin-ozellikleri-nelerdir.html.

Mecme'u'l-fıkhi'l-İslâmî. “el-İstihâle ve'l-istihlâk ve'l-mevâddü'l-idâfiyye fi'l-gıdâ ve'd-devâ". Erişim: 23 Temmuz 2018. http://www.iifa-aifi.org/2392.html.

Türkiye Diyanet Vakfı İslâm Araştırmaları Merkezi İslam Ansiklopedisi. "Necis Kelimesinin Ansiklopedi'de Kullanımı”. Erişim: 31 Ocak 2018. http://www.islamansiklopedisi.info. 